\title{
Long-term Assessment of Floodplain Reconnection as a Stream Restoration Approach for Managing Nitrogen in Groundwater and Surface Water
}

\author{
Paul Mayer ( $\sim$ mayer.paul@epa.gov) \\ US Environmental Protection Agency https://orcid.org/0000-0002-8550-1386 \\ Michael Pennino \\ US Environmental Protection Agency Office of Research and Development \\ Tammy Newcomer-Johnson \\ US Environmental Protection Agency Office of Research and Development
}

\section{Research Article}

Keywords: chloride, denitrification, floodplain reconnection, geomorphology, hydrology, groundwater, Minebank Run, nitrate, restoration, surface water, urban stream

Posted Date: June 21st, 2021

DOl: https://doi.org/10.21203/rs.3.rs-334865/v1

License: (9) This work is licensed under a Creative Commons Attribution 4.0 International License. Read Full License 


\section{Abstract}

Stream restoration is a popular approach for managing nitrogen in degraded, flashy urban streams. Here, we investigated the long-term effects of geomorphic stream restoration on riparian and in-stream $\mathrm{N}$ transport and transformation in an urban stream in the Chesapeake Bay watershed. We examined relationships between hydrology, chemistry, and biology using a Before/After-Control/Impact (BACl) study design to determine how flashiness and $\mathrm{N}$ concentrations and flux changed after the restoration. We examined two independent surface water and groundwater data sets collected from 2002-2012 at our study sites in the Minebank Run watershed, modeled $\mathrm{N}$ flux, and compared our data to similar long-term data from the Baltimore Ecosystem Study LTER (BES) that served as reference sites. Restoration was completed during 2004 and 2005. Afterward, the monthly flashiness index, based on mean monthly discharge, decreased over time from 2002 and 2008. Groundwater nitrate $\left(\mathrm{NO}_{3}{ }^{-}\right)$concentrations trended slightly downward over time after the restoration at the restored site while dissolved organic carbon (DOC) concentrations trended upward whereas no trends were observed at the control site. Comparisons of $\mathrm{NO}_{3}{ }^{-}$concentrations with $\mathrm{Cl}^{-}$concentrations and specific conductance in both groundwater and surface water suggested that $\mathrm{N}$ reductions over time at the restored sites were not due to dilution. Similar patterns at $\mathrm{BES}$ sites suggested that declining $\mathrm{NO}_{3}{ }^{-}$was a function of restoration and watershed management, not larger regional factors such as decreased atmospheric inputs. $\mathrm{DOC}$ and $\mathrm{NO}_{3}{ }^{-}$were negatively related before and after restoration suggesting $\mathrm{C}$ limitation of $\mathrm{N}$ transformation. Long-term trends in surface water $\mathrm{NO}_{3}{ }^{-}$based on USGS data showed downward trends after restoration at both the restored and control sites while specific conductance showed no trend, suggesting that load reductions were not responsible for $\mathrm{NO}_{3}{ }^{-}$patterns. Modeled $\mathrm{NO}_{3}{ }^{-}$flux decreased post restoration in both the short and long-terms. Groundwater $\mathrm{NO}_{3}{ }^{-}$concentrations varied among stream features suggesting that some engineered features may be functionally better at creating optimal conditions for $\mathrm{N}$ removal. However, some engineered features eroded and failed post restoration thereby reducing efficacy of the restoration to reduce flashiness and $\mathrm{NO}_{3}{ }^{-}$flux. $\mathrm{N}$ management via stream restoration will be most effective where flashiness can be reduced, and DOC made available for denitrifiers. Stream restoration may be an important component of holistic watershed management including stormwater management and nutrient source control.

\section{Introduction}

Urban streams transport nitrogen $(\mathrm{N})$ to downstream waters because channel degradation from flashy runoff, incision, and floodplain disconnection impair $\mathrm{N}$ transformation and uptake (Paul and Meyer 2001). Stream restoration designed to repair and reconnect stream channels, is an increasingly popular approach for managing $\mathrm{N}$ in urban streams. Such restoration attempts to improve hydrologic conditions favorable for $\mathrm{N}$ transformation and denitrification by reducing flashiness, increasing residence times, and adding organic carbon for denitrifiers (Mayer et al. 2010b: Duan et al. 2019). A recent synthesis suggested that there is potential for reducing $\mathrm{N}$ through stream restoration (Newcomer Johnson et al. 
2016), though it is not clear which methods are most efficient. Identifying restoration BMPs is critical for establishing protocols to meet nutrient management goals in watersheds like the Chesapeake Bay, USA where this study was conducted. (Urban Stormwater Work Group 2020). While some restoration approaches have shown short-term benefits (Kaushal et al. 2008a; Filoso and Palmer 2011; Filoso et al. 2015), most projects receive little or no post-restoration assessment (Bernhardt et al. 2005; Hassett et al. 2005). Most stream restoration studies are short-term employing space for time replacements examining restored and unrestored, reference sites simultaneously. Even fewer studies have examined groundwatersurface water interaction in urban or restored streams (Bukaveckas. 2007; Striz and Mayer 2008; Mayer et al. 2010b). Our research was intended to fill a gap in long-term studies of restoration, improve our understanding of $\mathrm{N}$ behavior in groundwater and surface water of restored streams, and elucidate possible BMPs for $\mathrm{N}$ management in urban ecosystems.

Here, we investigated the long-term effects of geomorphic stream restoration on riparian and in-stream $\mathrm{N}$ transport and transformation. We examined relationships between hydrology, chemistry, and biology in Minebank Run, a geomorphically degraded urban stream near Baltimore, Maryland, USA, in the Chesapeake Bay watershed. Minebank Run exhibited "urban stream syndrome" characteristics (Walsh et al. 2005), including eroded stream banks and flashy hydrology stemming from altered runoff from impervious surfaces (Doheny et al. 2006). Channel incision and meandering had exposed buried stormwater and sewer infrastructure prompting Baltimore County Department of Environmental Protection and Sustainability (BCDEPS) to restore Minebank Run in two phases, first, an upstream section in 1999 and, second, a downstream section in 2004 and 2005. We hypothesized that stream restoration designed to reconnect the stream to its floodplain would reduce surface and groundwater nitrogen concentration by creating hydrologic conditions that positively affect microbial activity, such as denitrification, in stream banks and hyporheic zones (Mayer et al. 2010b).

Naturally flowing stream channels are hydrologically connected to their floodplains. Urban streams often are disconnected from their floodplains because of stream channel incision from flashy stormwater runoff (Paul and Meyer 2001), altered subsurface flow from engineered urban karst (Kaushal and Belt 2012), and burial in pipes (Beaulieu et al. 2014; Pennino et al. 2014; Beaulieu et al. 2015). However, increasing hydrologic connectivity at the groundwater-surface water interface can foster "hot spots" and "hot moments" of $\mathrm{N}$ removal via denitrification when proper redox conditions develop and when inorganic $\mathrm{N}$ and organic $\mathrm{C}$ are available to denitrifying bacteria in the subsurface sediments (Hedin et al. 1998, Sobczak and Findlay 2002, Sobczak et al. 2002; McClain et al. 2003; Vidon et al. 2010). Current stream restoration protocol in the Chesapeake Bay region focuses on reconnecting floodplains as the most effective way to improve $\mathrm{N}$ uptake in urban streams (Urban Stormwater Work Group 2020). To test the efficacy of floodplain reconnection to reduce $\mathrm{N}$ in groundwater and surface water of degraded streams, we examined two independent groundwater and surface water datasets collected at our intensive study site, and we compared data that we collected with that from streams of the Baltimore Ecosystem Study (BES) Long Term Ecological Research Site (LTER; 
(https://baltimoreecosystemstudy.org/). We targeted stream reaches for intensive study where channel geomorphology was reengineered to reconnect hydrology. We use both empirical and modeling approaches to corroborate results and examined our site both before and after restoration. Our results are intended to inform future stream restoration efforts designed to manage $\mathrm{N}$ in urban ecosystems.

\section{Materials And Methods}

\section{Study design}

We investigated how stream restoration influenced $\mathrm{N}$ flux and concentration in groundwater and surface water at Minebank Run (Baltimore County, Maryland, USA) from November 2001 to October 2008. Studies of biogeochemistry, geomorphology, hydrology, salinity dynamics, and denitrification processes at Minebank Run have been published elsewhere (e.g., Mayer et al. 2003; Groffman et al. 2005; Doheny et al. 2006; Doheny et al. 2007; Kaushal et al. 2008a; Gift et al. 2010; Striz and Mayer 2008; Klocker et al. 2009; Mayer et al. 2010b; Newcomer et al. 2012; Harrison et al. 2011; Doheny et al. 2012; Harrison et al. 2012a; Harrison et al. 2012b; Mayer et al. 2013; Harrison et al. 2014; Cooper et al. 2014; Pennino et al. 2016; Wood et al. this issue). Here, we sought to place our research in the context of assessing the restoration of ecological processes and the identification of factors limiting those processes (Palmer 2009). Our specific objectives were to examine relationships among $\mathrm{DOC}, \mathrm{NO}_{3}{ }^{-}$, and $\mathrm{Cl}^{-}$in the surface water and groundwater pre- and post-restoration by employing a Before/After-Control/Impact (BACl) study design (Underwood 1992; Thompson et al. 2018). Our study used both long-term monitoring of a stream before and after restoration with intensive groundwater and surface water characterization, utilizing two independent data sets to produce empirical and modeling results. We used multiple data sets, including our own empirical data, USGS stream gage data, and published data from the BES LTER to develop corroborative nitrogen flux models spanning pre- and post-restoration study periods. We expected that nitrogen processing would be controlled by geomorphology, hydrology, and carbon supply.

\section{Study area}

Minebank Run is a $2^{\text {nd }}$ order urban stream located within an $8.47 \mathrm{~km}^{2}$ watershed within Baltimore County, Maryland, USA in the eastern section of the Piedmont physiographic province $\left(39^{\circ} 24^{\prime} 43^{\prime \prime} \mathrm{N}\right.$ and $76^{\circ} 33^{\prime} 12^{\prime \prime} \mathrm{W}$; Figure 1). Minebank Run flows in a northeasterly direction at approximately a $1 \%$ grade for $5.2 \mathrm{~km}$, where it enters Gunpowder Falls, eventually draining into Chesapeake Bay (Doheny et al. 2006). Land use in the Minebank Run watershed is over $80 \%$ urban/suburban (Doheny et al. 2006). Between 1960-70s, rapid urbanization led to severe channel degradation that was addressed by installing concrete flumes in the channel, which, by the 1990s, had been eroded out of place (Sortman 2004). The high proportion of impervious surface in the watershed, including the Interstate-695 Beltway, in a region of significant topographic relief, combined to produce flashy hydrology, eroded banks, incised channel bed, and general geomorphic instability. Hydrographs of storm events at Minebank Run (Doheny et al. 2006) are typical of urban streams in areas of high impervious surface (Paul and Meyer 2001). 
Urban development around Minebank Run predates stormwater management regulations implemented in mid-1980's, and thus, uncontrolled runoff entering the stream was a significant water quality problem. Portions of the channel were encased in concrete, thereby increasing the flashiness of storm flows. Sewer lines and storm drains were eroded and exposed. Riparian buffers were cleared for residential and commercial development.

Before restoration, the study reach was characterized by channel incision of 2-3 $\mathrm{m}$, revealing bedrock in some places and causing lateral movement of the stream that impacted property and sewer infrastructure. Pre-restoration channel width ranged from 0.15-15.5 m, and depth ranged from 0.04-0.9 $\mathrm{m}$, yielding channel cross-sectional areas ranging from $0.007-13.908 \mathrm{~m}^{2}$ (Doheny et al. 2006). Mean bank height along the study reach was $0.77 \pm 0.11 \mathrm{~m}$ (Mayer 2010b) with some extremely incised banks up to $1.5 \mathrm{~m}$ (Figure 2).

Phase I of the restoration, which addressed the upstream 2,400 $\mathrm{m}$ of stream beginning from the headwaters, began in 1999 and was completed in 2002. Phase II of the restoration, lasting from June 2004 to February 2005, addressed the remaining 3,300 $\mathrm{m}$ of the stream to the confluence of the Gunpowder River (USEPA 2006; Doheny et al. 2012). The restored study site is in Cromwell Valley Park (CVP) in approximately the middle of the $3300 \mathrm{~m}$ of the Phase II restoration reach and is referred to as restored site (Figure 1). The control study site is in the Intervale (IV) neighborhood of Towson, MD, USA in approximately the middle of the $2400 \mathrm{~m}$ phase I restoration reach and is referred to as the control site (Figure 1). The control and restored reaches are $2.4 \mathrm{~km}$ apart. The restoration included re-engineering approximately $1800 \mathrm{~m}$ of mainstem channel and $600 \mathrm{~m}$ of tributary channels (Sortman 2004).

Throughout the $5.2 \mathrm{~km}$ length of Minebank Run, various stream restoration techniques were used based on the condition of the channel and surrounding land use and infrastructure. For example, the stream channel was redesigned to move the thalweg away from an exposed sewer line to protect against further erosion and channel meandering (Figure 2). At two points, the channel was redesigned to reduce bank erosion by creating oxbow wetlands (Harrison et al. 2012a, Harrison et al. 2012b; Harrison et al. 2014), which effectively straightened the channel but allowed for greater overbank flow and stormwater retention. Prior to restoration, about $40-70 \%$ of the reach was riffles with runs and pools making up the remainder whereas, after restoration, the proportions of riffles, runs, and pools were more equitable at about $30-40 \%$ each (Doheny et al. 2012).

The restoration was intended to reconnect the stream channel with the floodplain by mimicking natural valley and floodplain morphology. For example, the project included step-pool and pool-riffle features as well as a stable meander pattern and cross-section. Natural channel design methods (Rosgen 1996, Rosgen 2011) were applied to control flow and erosion by a) raising the stream bed by filling the channel with gravel and cobble, b) removing concrete liners, c) reconstructing point bars, riffles and meander features, d) creating step-pool structure, e) armoring banks, f) creating oxbow wetlands, and g) revegetating the riparian zone (Sortman 2004; Duerksen and Snyder 2005). The restoration corresponded to typologies A, C, and I as described in Newcomer-Johnson et al. (2016). 
Although the approach to stream restoration at Minebank Run was primarily intended to address channel erosion and protect sewer infrastructure, we hypothesized that restoration could also affect the hydrology and biogeochemistry of the system (Mayer et al. 2003; Figure 3). Specifically, we speculated that the physical manipulations designed to accommodate the change in stream discharge rates would also have the potential to change surface and groundwater hydrology (Bukaveckas 2007, Tague et al. 2008) and reduce the hydrologic drought common in urban streams (Groffman et al. 2003). We speculated that the approach of reshaping the banks and raising the stream bed to eliminate bank incision also might allow carbon-rich riparian soils to become saturated and/or remain wetter, resulting in biogeochemical conditions favorable for nutrient transformations (Kaye et al. 2006). We expected flow control structures installed in the stream channel to reduce erosion also may trap organic matter long enough to create enriched anoxic zones conducive for denitrification to occur (Groffman et al. 2005). We also expected revegetating the riparian zone would provide litter inputs and root biomass to supply carbon to denitrifiers (Gift et al. 2010).

\section{Precipitation and hydrology}

Daily, monthly, and annual precipitation data for the study period (2002-2012) was downloaded from the PRISM Climate Group (https://prism.oregonstate.edu/explorer/; latitude: 39.4200/-76.5788). Stream discharge $\left(\mathrm{m}^{3} / \mathrm{s}\right)$ was measured at 5-minute intervals at Minebank Run restored CVP with an automated USGS stream gage (USGS ID 0158397967, Minebank Run near Glen Arm, Maryland, USA; http://waterdata.usgs.gov/nwis/uv?0158397967) by the USGS from 2002-2012. Daily mean stream discharge averaged for a 2-week period closest to each water chemistry collection point were used to construct regression models of the relationship between discharge and chemistry. While there is no stream gage at the control IV site, discharge measurements and samples collected by USGS are available (USGS ID 0158397925); https://waterdata.usgs.gov/md/nwis/inventory/?site_no=0158397925).

\section{Seasonal groundwater and surface water chemistry}

Groundwater and surface water were collected during 19 sampling events at the restored CVP reach (2001 - 2008) and 14 corresponding sampling events at the control IV reach (2003 - 2008). Sampling dates before 26 May 2004 are considered pre-restoration and sampling dates after 2 March 2005 are post-restoration. At CVP, groundwater and surface water were collected 9 times CVP pre-restoration (28-30 Nov 2001, 5-7 March 2002, 6-9 May 2002, 22-25 July 2002, 15-17 Oct, 2002, 7-9 April 2003, 29-31 July 2003, 15-17 Oct 2003, 10-12 May 2004,) and 10 times post-restoration (29 Nov-1 Dec 2005, 24-27 April 2006, 28-30 Aug 2006, 5-6 Dec 2006, 16-19 April 2007, 26-27 July 2007, 27-29 Nov 2007, 21-24 April 2008, 7-8 July 2008, 27-29 Oct 2008). Groundwater and surface water were collected at control IV beginning April 2003 and continuing through Oct 2008 for 14 corresponding sampling dates.

Groundwater was collected from the piezometers using low-flow pumping methods (Puls and Barcelona 1996) with a peristaltic pump through a flow cell and multi-meter instrument (Hach Co., Loveland, CO, 
USA) Surface water was collected via peristaltic pump for consistency with groundwater sampling. Field measurements for all samples included dissolved oxygen (DO; $\mathrm{mg} / \mathrm{L}), \mathrm{pH}$, temperature $\left(\mathrm{C}^{\circ}\right)$, oxidation reduction potential (ORP; $\mathrm{mV})$, and specific conductance $(\mathrm{mS} / \mathrm{cm})$. Samples for lab analysis were stored on ice and acidified to $\mathrm{pH} 2$ and/or filtered with 0.45 -micron filters, depending on analysis.

Piezometers were installed along transects aligned perpendicular to stream flow in groups of 3 (one group in the channel, and one group each on either bank) at 61,122, and $183 \mathrm{~cm}$ below the surface to capture longitudinal and lateral flow (as described in Striz and Mayer 2008; Kaushal et al. 2008a).

Transects crossed the stream at geomorphic and restoration features of interest including: cutbanks, gravel bars, terrace, riprap, and oxbows (Figure 2). A total of 18 piezometers and 2 surface water stations were sampled at control IV and 33 piezometers and 3 surface water stations were sampled at restored CVP. At control IV, piezometers were arranged in 2 transects located $38 \mathrm{~m}$ apart across 2 consecutive meander bends. At restored CVP, piezometers were located downstream of USGS stream gage 0158397967 (Figure 2) and arranged in 3 transects (71 m and $49 \mathrm{~m}$ apart). After restoration, some piezometers were replaced at the approximate original pre-restoration locations, where possible, or in comparable locations along the new post-restoration channel. Restoration involved redesigning the channel to fill heavily incised reaches that threatened damage to sewer infrastructure and, in the process, two bends in the channel were cut off to create oxbow wetlands (Figure 2) that were the focus of previous studies (Harrison et al. 2012a).

\section{Bi-weekly surface water chemistry}

Independent of the 19 groundwater EPA sampling episodes described above, a second set of surface water samples for $\mathrm{NO}^{-}$and specific conductance was collected by USGS (USGS National Field Manual; https://www.usgs.gov/mission-areas/water-resources/science/national-field-manual-collection-waterquality-data-nfm?qt-science_center_objects=0\#qt-science_center_objects) approximately every 2 weeks at restored CVP ( $N=278$ sampling events) beginning 5 March 2002 and beginning 3 June 2004 at control IV ( $N=201$ sampling events), and continuing at both sites until 30 June 2008, capturing both pre- and post-restoration periods.

\section{Reference sites: eight BES LTER streams with different land uses}

We also compared Minebank Run to eight nearby reference streams included in the Baltimore BES LTER network of urban study streams (https://baltimoreecosystemstudy.org/). The BES LTER streams include urban and suburban degraded streams, a stream in an agricultural area, and a forested reference stream. We used surface water chemistry data collected approximately weekly from 2002-2008 at 9 BES LTER stream study sites (Figure 4). The Gwynns Falls urban streams at BES LTER were selected because they are near Minebank Run (Figure 4) and are subject to similar urban influences on hydrology and flashy 
flows and managed with stormwater BMPs, stream restoration, and/or sewer repairs. McDonogh, the agricultural stream, is more heavily influenced by fertilizers than from urban runoff. Baisman Run and Pond Branch are in the Gunpowder Falls watershed, separate from Gwynn's Falls, which is in the Patapsco River watershed. However, both watersheds, and Minebank Run, are in the Piedmont physiographic region. Baisman Run is in an area without sewer infrastructure but with septic systems while Pond Branch is a forested reference stream. All streams were assumed to be potentially influenced by atmospheric inputs of nitrogen (Lovett et al. 2000, Eshleman et al. 2013).

\section{Laboratory chemical analyses}

Chemical analyses followed methodology described in APHA (1998), USEPA (1983), and USGS (USGS National Water Quality Laboratory: https://www.usgs.gov/labs/nwql). Dissolved organic carbon (DOC) was measured directly on a Tekmar-Dohrmann instrument (Teledyne Technologies Inc., Los Angeles, CA, USA) via the UV-persulfate digestion method. Nitrite $\left(\mathrm{NO}_{2}{ }^{-}\right)$and nitrate $\left(\mathrm{NO}_{3}{ }^{-}\right)$were measured on unfiltered samples using a Lachat Flow Injection Analyzer (Hach Co., Loveland, CO, USA). Because nitrite was negligible in our samples, we refer to combined nitrite and nitrate as nitrate $\left(\mathrm{NO}_{3}{ }^{-}\right) \cdot \mathrm{Cl}^{-}$was measured using capillary electrophoresis with indirect UV detection (Waters Corp., Milford, MA, USA).

\section{Estimation of $\mathbf{N}$ fluxes and hydrologic metrics}

Changes in $\mathrm{NO}_{3}{ }^{-}$flux were estimated using the $\mathrm{R}$ package EGRET (Exploration and Graphics for RivEr Trends) created by the USGS (Hirsch and De Cicco 2015), along with mean daily discharge and concentration data collected every 2 weeks at the Minebank Run stream gage (USGS 0158397967) by the USGS from 2002-2008 and by Pennino et al. (2016) from 2010-2012. The EGRET package applies the Weighted Regressions on Time, Discharge, and Season (WRTDS) smoothing method (Hirsch et al. 2010) for obtaining estimates of annual, monthly and daily flux, and annual flow normalized (FN) flux and concentrations. Flow normalization is used to remove the impact of year-to-year variations in discharge, which helps in assessing changes over time due to changes in the watershed (Medalie et al. 2012). For the FN flux, the mean daily discharge for a particular day is averaged across all years of the data and then multiplied by the concentration on that day (instead of just using the concentration and mean daily Q of that particular day) (Medalie et al. 2012). Daily, monthly, and annual precipitation data for the study period (2002-2012) was downloaded from the PRISM Climate Group (https://prism.oregonstate.edu/explorer/) at the following latitude and longitude coordinates: 39.4200/-76.5788.

We calculated the flashiness index, a metric to assess the variability in mean daily discharge over a given period of time (Baker et al. 2004, Poff et al. 2006, Sudduth et al. 2011, Violin et al. 2011). Greater hydrologic flashiness would indicate more rapid changes in discharge from one day to the next as is more typical in urban streams in watersheds with high impervious surface (Konrad et al. 2005, Walsh et 
al. 2005, Meierdiercks et al. 2010, Smith et al. 2013, Loperfido et al. 2014). Additionally, we applied the same methodology to precipitation data to calculate a "precipitation Flashiness Index," based on mean daily rainfall data.

$\mathrm{NO}_{3}{ }^{-}$Flux and the flashiness index were calculated over two different time periods: using just the USGS concentration dataset from 2002-2008 and including an additional concentration dataset collected from 2010-2012 (Pennino et al. 2016). The $\mathrm{NO}_{3}{ }^{-}$concentrations were taken from the same Minebank Run USGS gage station and show similar means and ranges between the two datasets (Figure S1).

\section{Statistical analyses}

We used ANOVA analysis to test for differences in chemistry (nitrate, dissolved organic carbon and chloride concentrations) between groundwater and surface water and between pre-restoration and postrestoration periods at restored CVP and control Intervale. Tukey's post-hoc test was performed to compare means during the pre-restoration and post-restoration periods, respectively. We used regression analysis to test for relationships in nitrate and chloride over time. Data were analyzed using Systat 13.0 and SigmaPlot 14.0 software (https://systatsoftware.com).

\section{Results}

\section{Precipitation trends and hydrologic response to stream- floodplain reconnection}

Annual and monthly precipitation during the study period was greatest in 2003, 2006, and 2011 (Figure 5). Similarly, discharge was generally highest in 2003, 2004, 2006, 2010, and 2011 (Figure 6). The highest mean daily discharge days occurred on 27 Oct 2003, 8 Oct 2005, 13 Aug 2008, 11 Sept 2009, 26 Dec 2009, 30 Sept 2010, 10 March 2011, 7 September 2011, and 29 October 2012 (Figure 6c). The top 10 peak flow events occurred on 12 June 2003, 8 Oct 2005, 25 June 2006, 23 July 2008, 13 Aug 2008, 28 Aug 2009, 14 Aug 2011, 7 Sept 2011, 1 June 2012, 14 Aug 2012 (Figure S2).

A fundamental objective of the restoration was to reduce flashy flows during precipitation events. Monthly flashiness index, based on mean monthly discharge, decreased over time between 2002 and 2008 (Figure 7a), but when extending the timeframe from 2002-2012, the flashiness index no longer shows a decline (Figure 7b). Similarly, when specifically comparing the pre-restoration period (20022004 ) with the post restoration period of 2005-2008, there is a decline in the stream flashiness index ( $p=$ 0.03 , Figure $8 \mathrm{a})$, but there is no difference when the post-restoration period is extended to $2012(p=0.11$, Figure 8b). By comparison, the flashiness of daily rainfall data (precipitation flashiness index) shows the opposite pattern with an increase in variability post-restoration $(p=0.05)$ in the 2002 to 2008 period and no significant change in the 2002 to 2012 period ( $p=0.14$, Figures S3, S4). 


\section{Seasonal groundwater and surface water chemistry}

\section{Groundwater vs surface water chemistry}

Pre- and post-restoration groundwater and surface water $\mathrm{NO}_{3}{ }^{-}$concentrations did not differ $(p \geq 0.2$; Table 1; Figure 9) at either the restored CVP reach or the control IV site (Table 1). In other words, groundwater resembled surface water at both reaches, although surface water $\mathrm{NO}_{3}{ }^{-}$at control IV $(1.12 \pm$ $0.06 \mathrm{mg} / \mathrm{L})$ trended weakly higher $(p=0.09)$ than groundwater at control IV $(0.97 \pm 0.04)$ after restoration, with mean concentration becoming similar to $\mathrm{NO}_{3}{ }^{-}$concentrations at the restored CVP reach $(1.08 \pm 0.07$ $\mathrm{mg} / \mathrm{L}$; Table 1).

Prior to restoration there was no trend at restored CVP in groundwater $\mathrm{NO}_{3}{ }^{-}$concentration $\left(\mathrm{R}^{2}=0.003, p=\right.$ 0.6; Table 3; Figure 9). However, groundwater $\mathrm{NO}_{3}{ }^{-}$trended weakly downward over time after the restoration at the restored CVP reach $\left(\mathrm{R}^{2}=0.017, p=0.03\right.$; Table 3; Figure 9). No trend was observed in surface water $\mathrm{NO}_{3}{ }^{-}$concentration either before or after the restoration at the restored CVP reach, suggesting that $\mathrm{NO}_{3}{ }^{-}$transformations occurred only after restoration in $\mathrm{NO}_{3}{ }^{-}$stored in groundwater. No trends were observed at the control IV reach, for groundwater or surface water $\mathrm{NO}_{3}{ }^{-}$during the postrestoration period ( $p=0.6$; Table 3 ; Figure 9 ). However, the significant positive trend in surface water $\mathrm{NO}_{3}{ }^{-}$during the pre-restoration period $(p=0.005$; Table 3$)$ may be a function of small sample size.

DOC was always significantly higher in surface water than in groundwater both before and after restoration at the control IV and the restored CVP reaches ( $p<0.001$; Table 1; Figure 9), suggesting that DOC was transported in surface water without being stored in groundwater or because DOC was consumed while in the subsurface. Groundwater and surface water $\mathrm{Cl}^{-}$concentrations were similar at the restored CVP reach both before and after restoration ( $p \geq 0.13$; Table 1 ; Figure 9$)$. However, at the control IV reach, surface water $\mathrm{Cl}^{-}$was double that in the groundwater both before and after restoration $(p<$ 0.001 ; Table 1), suggesting that local runoff events in the headwaters influenced surface water salt chemistry. Chloride concentrations at the downstream restored CVP reach (Figure 9) were chronically elevated compared to the upstream control IV reach due to effects of a major freeway that received heavy deicer salt inputs. However, groundwater was a reservoir for salt loads (Cooper et al. 2014), leading to similar groundwater and surface water $\mathrm{Cl}^{-}$concentrations downstream (Figure 9).

Prior to restoration there was no trend at restored CVP in groundwater DOC concentration $(p=0.5$; Table 3; Figure 9). However, groundwater DOC trended upward over time after the restoration at the restored CVP reach $\left(\mathrm{R}^{2}=0.022, p=0.01\right.$; Table 3$)$ in opposite trend to groundwater $\mathrm{NO}_{3}{ }^{-}$concentration $(p<0.03$; Table 3). No such trends were evident in surface water DOC at restored CVP $(p>0.3$; Table 3$)$. No trend was observed in groundwater DOC at the control IV site during the pre-restoration period $(p=0.9$; Table 3; Figure 9), but a weak positive trend was observed in the post-restoration period $\left(R^{2}=0.019, p=0.07\right.$; 
Table 3). Surface water DOC at control IV showed a decreasing trend during the pre-restoration period ( $\mathrm{R}^{2}$ $=0.586, p=0.03$; Table 3 ), again perhaps owing to small sample size. No trend in surface water DOC was evident in the post-restoration period at control IV ( $p=0.13$; Table 3$)$.

\section{Groundwater vs surface water chemistry}

Groundwater $\mathrm{NO}_{3}{ }^{-}$concentration was significantly lower after restoration at the restored CVP reach $(p=$ 0.01 ; Table 2$)$ as was surface water $\mathrm{NO}_{3}{ }^{-}$concentration at restored CVP $(p<0.001$; Table 2; Figure 9$)$. However, groundwater $\mathrm{NO}_{3}{ }^{-}$concentration at the control IV reach did not differ after restoration $(p=0.2$, Table 2) and surface water $\mathrm{NO}_{3}{ }^{-}$concentration at control IV was higher on average post-restoration than pre-restoration ( $p=0.08$; Table 2; Figure 9$)$.

Neither surface water nor groundwater DOC differed after restoration at the restored CVP reach $(p \geq 0.6$; Table 2; Figure 9). Likewise, surface water DOC at the control IV reach did not differ after the downstream restoration ( $p=0.4$; Table 2; Figure 9$)$. However, groundwater DOC was much lower after the restoration at the control IV reach for reasons we are not able to ascertain $(p<0.001$; Table 2 : Figure 9$)$. This difference did not seem to propagate downstream to the restored reach suggesting that there were more local sources of organic matter that were transported to the stream.

Chloride is chronically higher at the downstream CVP site than the IV site because CVP is downstream of the I-695 Beltway, a significant source of road salts (Cooper et al. 2014). After restoration, however, the relationship between groundwater and surface water $\mathrm{Cl}^{-}$is more closely matched, suggesting stronger groundwater and surface water interaction. The IV site is characterized by flashier surface water $\mathrm{Cl}^{-}$ concentrations, perhaps due to local headwater sources and/or less riparian buffer, while ground water $\mathrm{Cl}^{-}$ at IV is generally low and less variable over time.

Groundwater $\mathrm{Cl}^{-}$concentrations at the restored CVP reach did not differ after the restoration $(p=0.4$; Table 2; Figure 9). However, surface water $\mathrm{Cl}^{-}$concentrations were lower after restoration $(p=0.02$; Table 2; Figure 9), suggesting lower inputs from road salts along the $1-695$ beltway during this period. Overall, groundwater $\mathrm{Cl}^{-}$concentration was lower during the post-restoration period at the control IV reach $(p=$ 0.01; Table 2; Figure 9) owing to high concentrations prior to the restoration, suggesting less storage or increased flushing in the subsurface during the post-restoration time period. Surface water $\mathrm{Cl}^{-}$trends did show increasing rate after the restoration (see next section). However, surface water $\mathrm{Cl}$ in groundwater did not differ at control IV after the restoration at CVP $(p=0.3$; Table 2; Figure 9).

Chloride trends in groundwater at the restored CVP reach shifted from negative $(p<0.001)$ to positive ( $p$ $=0.03$ ) after the restoration, suggesting an increasing rate of road salt application and/or increased storage of salts in the subsurface (Table 3). Surface water $\mathrm{Cl}^{-}$at restored CVP showed a negative trend before the restoration ( $p=0.06$; Table 3 ) but no such trend after the restoration ( $p=0.6$; Table 3$)$. Only 
during the post-restoration period was there a positive trend in $\mathrm{Cl}^{-}$concentration at the IV reach and only for groundwater $(p<0.001$; Table 3$)$. No other $\mathrm{Cl}^{-}$trends were observed at control IV ( $p \geq 0.3$; Table 3$)$.

\section{Relationship between $\mathrm{NO}_{3}{ }^{-}$and DOC}

Groundwater $\mathrm{NO}_{3}{ }^{-}$and $\mathrm{C}: \mathrm{N}$ molar ratios at both the restored CVP reach $(N=477 ; 2.15 \pm 0.35)$ and the control IV reach $(N=232 ; 3.17 \pm 0.97)$ showed the same negative curvilinear relationship (Figure 10). Highest $\mathrm{NO}_{3}{ }^{-}$concentrations were observed in piezometers where $\mathrm{C}: \mathrm{N}$ ratio was lowest. Low $\mathrm{NO}_{3}{ }^{-}$ concentrations approached zero in groundwater samples where C:N was about 10:1.

\section{Chemistry response to channel geomorphology}

$\mathrm{NO}_{3}{ }^{-}, \mathrm{DOC}$, and $\mathrm{Cl}^{-}$concentrations in groundwater differed among stream features at restored CVP reach before and after the restoration ( $p \leq 0.05$; Table 7). Before restoration, $\mathrm{NO}_{3}{ }^{-}$was highest in cutbanks (2.6 $\pm 0.3 \mathrm{mg} / \mathrm{L}$; Table 7) followed by concentrations below the stream channel and in terrace features $(1.53 \pm$ $0.06 \mathrm{mg} / \mathrm{L}$ and $1.51 \pm 0.08 \mathrm{mg} / \mathrm{L}$, respectively; Table 7). DOC was highest in the subsurface of the stream channel $(1.18 \pm 0.08 \mathrm{mg} / \mathrm{L}$; Table 7$)$, likely as a function of transport and groundwater-surface water mixing. $\mathrm{Cl}^{-}$was highest in groundwater of gravel bars associated with meander features and below the stream channel $(163.5 \pm 11.3 \mathrm{mg} / \mathrm{L}$ and $135.0 \pm 8.3 \mathrm{mg} / \mathrm{L}$, respectively; Table 7$)$ and lowest in cutbank features (59.8 $\pm 6.3 \mathrm{mg} / \mathrm{L}$; Table 7$)$.

After restoration, oxbows and rip rap structures became new features of the system. $\mathrm{NO}_{3}{ }^{-}$was highest in oxbow features $(2.52 \pm 0.25 \mathrm{mg} / \mathrm{L}$; Table 7$)$, suggesting higher retention of $\mathrm{N}$ at this floodplain reconnection feature (Harrison et al. 2012a). Cutbank features were mostly eliminated after the restoration, however, $\mathrm{NO}_{3}{ }^{-}$was relatively low for the few samples collected $(0.91 \pm 0.09 \mathrm{mg} / \mathrm{L}$; Table 7$)$. $\mathrm{NO}_{3}{ }^{-}$in the stream bed and at terrace features designed to connect the floodplain to the stream channel were similar (Table 7), suggesting again that the stream and terraced features were hydrologically connected. DOC remained highest $(1.23 \pm 0.06 \mathrm{mg} / \mathrm{L}$; Table 7) below the stream channel perhaps owing to higher transport of incoming organic matter mixing in the subsurface.

Chloride was highest at gravel bars and in the stream channel $(212.3 \pm 13.9$ and $128.5 \pm 3.3 \mathrm{mg} / \mathrm{L}$, respectively; Table 7), suggesting enhanced $\mathrm{Cl}^{-}$storage in these features. Chloride concentration was similar among stream channel, cutbank, oxbows, riprap, and terrace features (Table 7).

\section{Restoration effects on biweekly surface water chemical concentrations and fluxes}


Surface water $\mathrm{NO}_{3}{ }^{-}$concentration in the intensive surface water USGS surveys showed increasing trends prior to restoration and during construction at restored CVP $(p \leq 0.008$; Table 4; Figure 11). However, after restoration, $\mathrm{NO}_{3}{ }^{-}$trends declined steadily $(p \leq 0.001$; Table 4; Figure 11). Seasonal cycles were evident, with higher $\mathrm{NO}_{3}{ }^{-}$observed in winter with maximum concentrations $>4 \mathrm{mg} / \mathrm{L}$ before restoration and $>2$ $\mathrm{mg} / \mathrm{L}$ even after restoration (Table 4) when temperatures and microbial and plant activity were lower likely reducing uptake of $\mathrm{NO}_{3}{ }^{-} \cdot \mathrm{NO}_{3}{ }^{-}$was especially low $(0.23 \mathrm{mg} / \mathrm{L} ;$ Table 4$)$ during a severe drought in 2002 and then rose concurrently with a rapid shift to a wet season in 2003 (Figure 8). Similar trends occurred at control IV (Table 4; Figure 11), suggesting that seasonal and interannual $\mathrm{NO}_{3}{ }^{-}$cycles and runoff effects propagated downstream to the restored site.

Biweekly surface water sampling by USGS at restored CVP did not include regular $\mathrm{Cl}^{-}$analysis. Instead, we relied on specific conductance as a surrogate measure of $\mathrm{Cl}^{-}$which can reflect similar patterns as $\mathrm{Cl}$ flux (Cooper et al. 2014; Pennino et al. 2016). Like Cl', specific conductance was chronically higher at the downstream restored CVP site than upstream at control IV (Figure 12). Specific conductance was relatively variable, exhibiting peaks and outliers (Figure 12). Specific conductance increased over time at restored CVP and control IV prior to restoration ( $p \leq 0.05$; Table 4 ). While post-restoration specific conductance trends were not significant at either restored CVP or control IV ( $p>0.11$; Table 4$)$, the overall trends appear to be increasing, suggesting that Minebank Run water chemistry was influenced by ion inputs from road salts and that stormwater runoff is a factor dictating stream chemistry throughout this system (Figure 12).

\section{Surface water $\mathrm{NO}_{3}{ }^{-}$trends at BES LTER reference streams}

The BES LTER streams represent reference sites to our study sites at Minebank Run because they are urban streams in similarly degraded watersheds that have been variously impacted by urbanization but managed for water quality improvements via stream restoration, stormwater management, and sewer repair. Like Minebank Run, declining trends in $\mathrm{NO}_{3}{ }^{-}$were observed at two BES LTER streams, Gwynns Falls at Carroll Park (urban; $p=0.01$ ) and at Glyndon (suburban headwaters; $p \leq 0.001$; Table 5; Figure 18). Nitrate increased at the Gwynns Falls Gwynnbrook Ave site (suburban; $p=0.04$; Table 5, Figure 18). There was no trend at Baisman Run ( $p=0.07$; Table 5; Figure 18) which is in a suburb with septic instead of piped sewer infrastructure. There was no $\mathrm{NO}_{3}{ }^{-}$trend at forested reference site Pond Branch $(p=0.7)$ which should be affected by atmospheric and natural soil inputs alone. There was a strong increasing trend in $\mathrm{NO}_{3}{ }^{-}$at $\mathrm{McD}$ onogh $(~ p<0.001$; Table 5; Figure 18), the agricultural site most affected by manure fertilizers inputs and where there were no significant stream restoration efforts.

Like Minebank Run, increasing trends in $\mathrm{Cl}^{-}$were observed among some of the $8 \mathrm{BES}$ LTER streams examined (Table 6). Chloride concentration increased over time period 2002-2008 at Baisman Run, McDonogh, and Pond Branch streams (Analysis \#1; $p \leq 0.003$; Table 6). The remaining 5 streams exhibited numerous extreme peaks likely due to storm events. When those peaks were eliminated, 3 
additional BES LTER streams exhibited increasing $\mathrm{Cl}^{-}$trends over time ( $p \leq 0.025$; Analysis \#2; Table 6; Figure 19). Dead Run and Glyndon showed no trends ( $p>0.2$; Analysis \#2; Table 6; Figure 19). Increases at the urban and suburban sites suggest increasing runoff from road salts. However, increasing $\mathrm{Cl}^{-}$at Pond Branch ( $p<0.001$; Table 6; Figure 19) was unexpected because we assumed this reference stream would not be affected by saline runoff. The increasing $\mathrm{Cl}^{-}$trend at McDonogh, the agricultural site, may have been affected by fertilizers but unlikely from road runoff because of low road density $(p<0.001$; Table 6; Figure 19).

\section{Trends in $\mathrm{NO}_{3}{ }^{-}$fluxes from bi-weekly monitoring at Minebank Run}

Monthly $\mathrm{NO}_{3}{ }^{-}$flux estimates showed an increasing trend pre-restoration $\left(R^{2}=0.2, p=0.01\right)$, and a decreasing trend post-restoration from 2005-2008 $\left(R^{2}=0.13, p=0.01\right.$; Figure 13a), but there was no change in flux post-restoration from 2005-2012 $\left(R^{2}=0.003, p=0.26\right.$; Figure $\left.13 \mathrm{~b}\right)$. When comparing the monthly pre- and post-restoration monthly flux values, there is a significant decline in flux in the first three years post-restoration ( $p<0.001$; Figure 14a) and in the first seven years post-restoration $(p=0.01$; Figure $14 \mathrm{~b})$. When looking at trends in annual flux and flow normalized flux, there is a steady decline in both from 2002-2008 ( $p=0.01$ and $p<0.001$, respectively; Figure 15a). For the 2002-2012 period there a smaller though less pronounced decline in flow normalized flux $(p<0.001)$, but no significant decline in annual flux ( $p=0.22$; Figure 15b).

The EGRET package was also used to calculate mean annual flow normalized (FN) concentrations and we found that $\mathrm{FN}$ concentrations declined over the 2003-2008 period $\left(R^{2}=1.0, p<0.001\right.$; Figure 16a) and the 2003-2012 period $\left(R^{2}=0.99, p<0.001\right.$; Figure $\left.16 \mathrm{~b}\right)$. Additionally, we found a positive relationship between $\mathrm{NO}_{3}{ }^{-}$concentration and discharge and this had a less positive slope post-restoration $\left(R^{2}=0.01\right.$, $p=0.11)$ compared to pre-restoration $\left(R^{2}=0.01, p=0.22\right.$; Figure $\left.17 \mathrm{a}, \mathrm{b}\right)$ for both the 2003-2008 and 2003-2012 time periods.

\section{Discussion}

Chemistry trends at Minebank Run suggest that stream restoration involving floodplain reconnection has the potential to reduce $\mathrm{N}$ concentration and $\mathrm{N}$ flux at a reach scale. Previous work at Minebank Run has shown that when stream channels are restored to allow overbank flow, denitrification rates are higher than where the channel flows through high, incised banks (Kaushal et al. 2008a; Klocker et al. 2009). Surface water trends among BES LTER reference streams show similar trends in N over the same time period compared to Minebank Run, suggesting that stream restoration, stormwater BMPs and/or sewer repairs have also reduced $\mathrm{N}$ in certain watersheds over longer time scales. Declining trends in bioreactive $\mathrm{NO}_{3}{ }^{-}$corresponding to increasing trends in conservative $\mathrm{Cl}^{-}$and/or specific conductivity suggest that the decreases in $\mathrm{NO}_{3}{ }^{-}$are a function of biological uptake or denitrification (Mayer et al. 2010b). Below, we 


\section{Stream-floodplain reconnection (and other management activities) influences long-term $\mathbf{N}$ transport and retention}

Our study demonstrated that floodplain reconnection was an effective restoration approach for reducing $\mathrm{N}$ concentration and flux in an urban stream. Based on the BACl design, both groundwater and surface water $\mathrm{NO}_{3}{ }^{-}$decreased at restored $\mathrm{CVP}$ after the restoration despite no change in groundwater $\mathrm{NO}_{3}{ }^{-}$ concentration at the control site and an increase in $\mathrm{NO}_{3}{ }^{-}$in surface water upstream at IV. Furthermore, groundwater $\mathrm{NO}_{3}{ }^{-}$continued to trend downward after the restoration. These results suggest that the restoration was effective at a reach scale in reducing $\mathrm{NO}_{3}{ }^{-}$. Groundwater and surface water $\mathrm{Cl}^{-}$showed increasing trends after the restoration at both the control and restored reaches suggesting that declines in surface water $\mathrm{NO}_{3}{ }^{-}$concentration were not a function of dilution effects (Altman and Parizek 1995). While there was no change in mean DOC concentrations after restoration, increasing DOC trends may have contributed to improved uptake of $\mathrm{NO}_{3}{ }^{-}$by increasing availability of organic matter to denitrifiers.

Nearby BES LTER streams that received no restoration or $\mathrm{N}$ management during the study period (Pond Branch and Baisman Run) showed no declines in $\mathrm{NO}_{3}{ }^{-}$over time, unlike the restored stream at Minebank Run and the two BES LTER sites at Gwynns Falls, where stream restoration, sewer repair, and/or stormwater management had been applied. The positive trend in $\mathrm{NO}_{3}{ }^{-}$at Gwynns Falls at Gwynnbrook suggests that any management along this reach has not been effective or is overwhelmed by inputs from urbanization. The corresponding positive trends in $\mathrm{Cl}^{-}$at nearly all BES LTER sites suggest that runoff inputs from surrounding urban and suburban landscapes are significant even at the agricultural and reference sites. Therefore, negative or neutral trends in $\mathrm{NO}_{3}{ }^{-}$among streams with active nutrient management and/or restoration efforts suggests that such management is effective at stabilizing current $\mathrm{N}$ inputs, though significant reductions in $\mathrm{NO}_{3}{ }^{-}$at the $\mathrm{BES}$ streams or at Minebank Run will likely require additional management efforts and/or reductions in watershed nutrient inputs.

In addition to floodplain reconnection, other coinciding management changes may have played an additional role in explaining our observations. Declines in atmospheric inputs of $\mathrm{N}$ in the Chesapeake Bay area (Lovett et al. 2000; Linker et al. 2013), have contributed to corresponding declines in stream N (Eshleman et al. 2013; Reisinger et al. 2019). While atmospheric $\mathrm{N}$ declines in the area may have contributed to changes in chemistry at BES LTER sites and at Minebank Run, the lack of observable declines at the control IV reach over time suggests that any probable reduction in atmospheric inputs had a much lesser effect on $\mathrm{NO}_{3}{ }^{-}$flux at Minebank Run than did restoration. Furthermore, terrestrial inputs are unlikely to have declined over time across any of the stream sites given the consistent urbanization pressure. Thus, Minebank Run was processing chronic or increasing inputs of $\mathrm{N}$ due to increases in 
urbanization. Pond Branch, the forested reference BES LTER stream site showed very low $\mathrm{NO}_{3}{ }^{-}$levels, without a declining trend, suggesting that atmospheric inputs were not a major component of total $\mathrm{N}$. The lack of a $\mathrm{NO}_{3}{ }^{-}$trend at suburban Baisman Run where sewer infrastructure is absent also suggests that the elevated levels of $\mathrm{NO}_{3}{ }^{-}$observed at this stream are a function of anthropogenic inputs but that, without the benefit of repairs to sewer infrastructure, levels of $\mathrm{NO}_{3}{ }^{-}$were unaffected. Highly elevated and increasing $\mathrm{NO}_{3}{ }^{-}$levels at the $\mathrm{McD}$ onogh stream that show a distinct seasonal pattern, suggest that inputs from agriculture overwhelm any other watershed management efforts as well as potential benefits from reduction in atmospheric inputs. Minebank Run and all Gwynns Falls BES LTER sites showed declining surface water $\mathrm{NO}_{3}{ }^{-}$over the period of observation, 2002-2008. Unlike Pond Branch and Baisman Run, these streams are in watersheds where stream restoration, sewer repair, and/or stormwater management have been applied, suggesting that these efforts have contributed to reduced $\mathrm{N}$ flux (Reisinger et al. 2019). Restoration at Minebank Run appears to have made an impact on $\mathrm{NO}_{3}{ }^{-}$flux through improved groundwater-surface water interaction and the initial reconnection of the floodplain to the channel. However, with numerous structural failures appearing along the restored reach (see Figure S5a and b), long-term efficacy is in question.

\section{Evidence that altered stream morphology enhances $\mathbf{N}$ transformation by increasing retention times in stream features and floodplains}

The similarity of groundwater and surface water $\mathrm{NO}_{3}{ }^{-}$and $\mathrm{Cl}^{-}$at both the restored $\mathrm{CVP}$ reach and control IV reach suggests mixing of groundwater and surface water. $\mathrm{NO}_{3}{ }^{-}$and $\mathrm{Cl}^{-}$patterns among stream restoration features varied before and after restoration suggesting that some features were more retentive of $\mathrm{N}$. The oxbows created by the restoration had higher $\mathrm{NO}_{3}{ }^{-}$concentrations perhaps because they were designed to retain stormwater runoff (Harrison et al. 2014). However, these features promoted high rates of denitrification (Harrison et al. 2011), demonstrating that such wetlands have the potential to reduce $\mathrm{NO}_{3}{ }^{-}$in urban watersheds. The change in the proportions of riffles, runs, and pools may also have influenced the uptake of $\mathrm{NO}_{3}{ }^{-}$. The proportion of pools, which were found to have higher sediment denitrification potential than riffles (Harrison et al. 2012b), increased after restoration relative to riffles (Doheny et al. 2012), suggesting that altering stream geomorphology features may enhance $\mathrm{N}$ transformation by maintaining anaerobic conditions and microbial activity that stimulate denitrification (Harrison et al. 2012b).

$\mathrm{N}$ sink and source dynamics vary among geomorphic structures depending on the influence of geomorphology on hydrology and subsequent microbial activity (Munn and Meyer 1990, Jones and Holmes 1996, Kemp and Dodds 2002; Fisher et al. 2005). There was considerable change in channel morphology (e.g. increased proportions of riffles, run, pools, reduced sinuosity, reduced bank elevation 
and slope, reduced incision). Collectively, these changes influenced hydrology (i.e. flashiness), and thus nutrient transformation processes. Furthermore, boundary sheer stress was reduced, thereby reducing the erosive forces on the channel bed and banks of the stream (Doheny et al. 2007, Doheny et al. 2012). Boundary shear stress and mean velocity values for Minebank Run were generally greater than nonurban B or C channel types (Doheny et al. 2012; Doheny and Baker 2018). The slope of the shear stress regression line for Minebank Run is considerably flatter than those for non-urban streams suggesting that small changes in mean velocity and discharge result in large changes in boundary shear stress and susceptibility to erosion (Doheny and Baker 2018). Reducing shear stress, flashiness, and the subsequent scouring of organic matter and removal of debris dams may improve denitrification in urban streams (Groffman et al. 2005; Harrison et al. 2012b).

Altered stream morphology after stream restoration also likely contributed to a reduction in hydrologic flashiness at Minebank Run. A previous study at Minebank Run showed that restoration lessened the positive relationship between precipitation and daily peak discharge, suggesting that restoration reduced overall flashiness of the system (Pennino et al. 2016). In another Minebank Run study, channel depth in the restored CVP reach was unchanged by restoration, however, channel width increased, and, consequently, cross-sectional area increased which caused a proportional decrease in mean flow velocity for comparable discharges (Doheny et al. 2012). Increased stream surface area has been shown across stream restoration approaches to improve nutrient retention (Newcomer-Johnson et al. 2016; Grant et al. 2018). Therefore, the increase to cross-sectional area may have contributed to the reduction in $\mathrm{N}$ flux that we observed in this study. Previous studies at Minebank Run also showed that the proportion of riffles, runs, and pools changed after restoration. Prior to restoration, about $40-70 \%$ of the reach was riffles with runs and pools making up the remainder whereas, after restoration, the proportions of riffles, runs, and pools were more equitable at about 30-40\% each (Doheny et al. 2012).

\section{Enhanced hydrologic connectivity in stream restoration is linked to $\mathrm{N}$ retention and transformation}

The decline in post-restoration $\mathrm{NO}_{3}{ }^{-}$concentrations and flux is supported by previous studies at Minebank Run showing that restored low "connected" banks consistently had higher in situ denitrification rates (Kaushal et al. 2008a; Mayer et al. 2013). The restoration dramatically altered stream bed elevations in many places along the reach (Doheny et al. 2012) likely leading to improved connection between the stream channel and banks (Striz and Mayer 2008). Wider channel width and decreased channel incision may have increased hydrologic connectivity between groundwater and surface water and, thereby, affected denitrification rates (Groffman et al 2002, Groffman et al. 2003). Changes in channel morphology to a mix of runs, riffles, and pools may have also enhanced $\mathrm{N}$ uptake by increasing the turbulence along bioreactive microbial films that controls denitrification rates (Grant et al. 2018). The step-pool sequences, stream barbs, and meanders similar to those in low connected reaches have been shown to increase hydrologic residence times and nitrogen retention in transient storage zones at the 
riparian-stream interface (Kasahara and Hill 2006) relative to straighter runs (Hill et al. 1998, Gücker and Boechat 2004). Hydrologic flowpaths in the more connected bank may have fostered higher denitrification rates as was demonstrated in previous work at Minebank Run using conservative tracer injections showing that lateral groundwater inputs along the riparian-stream interface can be substantial (Klocker et al 2009).

Increased hydrologic connectivity at the groundwater-surface water interface can provide DO, N, and organic matter to microbes in subsurface sediments, and may foster "hot spots" for nitrogen removal via denitrification due to low redox conditions (Hedin et al. 1998, Sobczak and Findlay 2002). Like other urban streams, the groundwater-stream interface at Minebank Run is characterized by dynamic gradients of DO, nitrogen concentrations, and organic $\mathrm{C}$ where biogeochemical reactions like denitrification can take place (e.g. Jones and Holmes 1996, Hill et al 1998, Fellows et al. 2001, Sobczak and Findlay 2002).

\section{Additional importance of organic matter and potential role for enhancing $\mathbf{N}$ transformation}

DOC showed opposite trends to $\mathrm{NO}_{3}{ }^{-}$in groundwater after restoration at CVP, with increases in DOC, perhaps due to increased plant growth after restoration, which included stream bank planting (Gift et al. 2010) and/or less flashy flows which allowed accumulated carbon to be retained in the channel (Groffman et al. 2005). $\mathrm{NO}_{3}{ }^{-}$declined with increasing $\mathrm{C}: \mathrm{N}$ in a negative curvilinear trend suggesting that $\mathrm{N}$ transformation is $\mathrm{C}$ limited, a result consistent with previous studies at Minebank Run (Mayer et al. $2010 \mathrm{~b}$ ) as well as patterns across ecosystem types showing DOC limitation of denitrification (Taylor and Townsend 2010). N flux and uptake in urban streams is strongly influenced by $\mathrm{C}$ availability because the microbes respire $\mathrm{NO}_{3}{ }^{-}$during the denitrification process and utilize organic $\mathrm{C}$ as their energy source (Bernhardt and Likens 2002; Groffman et al. 2005). Organic C availability to microbes creates a high demand for $\mathrm{O}_{2}$, which fosters the anaerobic conditions necessary for denitrification (Tiedje 1982, Baker et al. 2000, Bernhardt et al. 2002). Therefore, factors that influence accumulation and processing of $C$ are strong regulators of $\mathrm{N}$ dynamics in streams. $\mathrm{NO}_{3}{ }^{-}$approached zero where $\mathrm{C}: \mathrm{N}$ was about 10:1 suggesting that management of stream $\mathrm{N}$ will be enhanced if riparian zones are kept intact to provide leaf litter as a C source (Wood et al., this issue), or where $\mathrm{C}$ is available from the rooting zone via exudates and decomposition (Gift et al. 2010), and where organic matter can be retained in the stream for denitrification (Groffman et al. 2005; Lazar et al. 2014). Current protocol for restoring streams in the Chesapeake Bay to manage $\mathrm{N}$ emphasizes engineering floodplains to maintain a zone of rooted vegetation to maximize $\mathrm{NO}_{3}{ }^{-}$transformation potential (Urban Stormwater Work Group 2020)

Our observation of consistently higher DOC in surface water versus groundwater at Minebank Run suggests that organic matter does not mix in the subsurface and/or is consumed rapidly. Previous work has shown that DOC concentration is highest in surface water and declines with depth in the channel (Mayer et al. 2010b) likely due to limited water influx into the hyporheic zone. Organic matter is more 
abundant in upper root zone layers (Gift et al. 2010) and declines with depth in riparian soils (Groffman et al. 2002). Furthermore, particulate matter may be less likely to remain entrenched in interstitial zones or persist in debris and leaf packs in flashy streams (Groffman et al. 2005), thereby limiting the availability of organic matter in the subsurface. Because DOC is a critical limit to denitrification, restoration techniques designed to more effectively supply DOC to hyporheic zones and floodplains can optimize $\mathrm{N}$ removal (Newcomer-Johnson et al. 2016; Duan et al. 2019).

Previous research at Minebank Run showed that denitrification enzyme activity (DEA) and microbial biomass $\mathrm{C}$ were both higher in hyporheic sediments (in and near stream piezometers) than in deep floodplain sediments suggesting that the hyporheic zone is responding to and processing $\mathrm{C}$ and $\mathrm{NO}_{3}{ }^{-}$ from upstream and/or riparian sources (Mayer et al. 2010b). These results also suggest that restoration that increases $C$ flow to these sediments could increase denitrification capacity of the stream ecosystem. At Minebank Run and other streams in the Baltimore area, denitrification potential was highest in organic debris dams and other features high in organic matter (Groffman et al. 2005). None of the stream features in Minebank Run were regions of high organic matter accumulation probably because flashy stream flows frequently wash debris from the channel and downstream. Also, pools in both the restored and unrestored reaches of Minebank Run had lower denitrification enzyme activity than pools from other streams in the Baltimore area (Groffman et al. 2005). Strong positive relationships at Minebank Run between root biomass and soil organic matter, and between soil organic matter and denitrification potential, suggests that deep rooted vegetation may be particularly important for maintaining an active denitrification zone in restored riparian zones (Gift et al. 2010). However, restoration that improves hydrologic connectivity in the hyporheic zone and floodplain so that organic matter reaches subsurface zones where there is low $\mathrm{DO}$ and adequate $\mathrm{NO}_{3}{ }^{-}$for anaerobic activity is key to enhancing denitrification.

\section{Reductions in $\mathrm{NO}_{3}{ }^{-}$flux and flow normalized concentrations post-restoration}

$\mathrm{NO}_{3}{ }^{-}$flux showed a significant decline in the 2005-2008 post restoration period compared to the 20022004 pre-restoration period, but the absolute $\mathrm{NO}_{3}{ }^{-}$flux and $\mathrm{FN}$ flux increased slightly during the 20102012 post-restoration period. Mean annual concentrations and flow normalized concentrations continued to decline during the full post-restoration period 2005-2012. There are several possible explanations for the increase in $\mathrm{NO}_{3}{ }^{-}$flux in 2010-2012 including greater mean annual discharge and the observed failure of many of the restoration features after 2008. There is evidence that damage occurred to the restored features by 2013 and, based on the flow record, there were likely damaging peaks in 2009, 2011, 2012 (personal communication, Ed Doheny, USGS; Figure S2). There were peak flow events $>30$ $\mathrm{m}^{3}$ /s at least three times between August of 2011 and June of 2013 (Figure S2). In 2008, there was evidence of erosion at the toe of the banks in some of the cross sections, in 2011-2012, particularly August through September 2011, which was a wet period due to tropical storms. Some restoration 
features were degrading and many of the cut banks had re-established themselves. Based on observations by USGS (Ed Doheny, personal communication), by 2013, the area downstream of the sampling wells at restored CVP looked like pre-restoration conditions with cut banks re-established, cross vanes buried and damaged, rock weirs collapsed, and without maintenance of the grade control of the channel bed (Figure S5a and b). By 2016, the restoration at CVP had largely reverted to a pre-restoration condition where incised banks had re-appeared and the stream was no longer connected to the floodplain. Additionally, the large oxbow feature created in 2004 to accept excess stormflow upstream of the USGS gage, had filled with sediment by 2016 (and perhaps as early as 2010) and was no longer functioning to accept stormflow connected to the channel (personal communication, Ed Doheny).

The failure of restoration features after 2008 may have not only contributed to less $\mathrm{NO}_{3}{ }^{-}$removal due to less biogeochemical processing, but also less attenuation of the discharge (Woltemade and Potter 1994, Hammersmark et al. 2008, Sholtes and Doyle 2011, Jacobson et al. 2015). This may partly explain why discharge was higher in 2010-2012 even though precipitation did not differ between the periods of 20052008 and 2010-2012 (Figure 14). Magnitude and intensity of individual storms may also have been a factor. Also, less infiltration and less attenuation of peak discharge may have occurred after the oxbow feature was dysfunctional and the stream was no longer connected to the floodplain (Fink and Mitsch 2007, Hudson et al. 2012, Harrison et al. 2014, Palmer et al. 2014). There may have been less removal of $\mathrm{N}$ from the stream compared to when the oxbows were at peak function in the first years after restoration (Harrison et al. 2014). Consequently, the increase in $\mathrm{N}$ flux in 2010-2012 may be explained by the higher discharge and lesser biogeochemical processing due to the geomorphic failure of the restoration features and it may explain why stream flashiness, which initially declined after restoration, increased by 2008 . Similarly, Thompson et al. (2018) observed little reduction in hydrologic flashiness at a reach scale at a restored stream in Maryland, USA.

Despite geomorphic failure of restoration features, the decline of flow normalized $\mathrm{NO}_{3}{ }^{-}$concentrations over time indicate that the stream was still able to continue removing $\mathrm{NO}_{3}{ }^{-}$through biogeochemical processing. Also, the lower slope of the $\mathrm{NO}_{3}{ }^{-}$concentration-to-discharge relationship during postrestoration compared to pre-restoration, indicates that, even at higher flows, $\mathrm{NO}_{3}{ }^{-}$concentrations were lower after the restoration, which confirms that the restoration improved biogeochemical $\mathrm{NO}_{3}{ }^{-}$uptake activity across a range of flows.

\section{Conclusion}

Our studies support the idea that in-stream processes and hydrologic connectivity between the stream channel and subsurface zones may influence $\mathrm{N}$ processing in urban streams (Craig et al. 2008, Kaushal et al. 2008a). Restoration activities focused on increasing hydrologic connectivity in riparian zones may enhance denitrification rates by increasing soil organic carbon availability and altering hydrologic flowpaths (e.g. Fennessy and Cronk 1997; Groffman et al. 2003; Boulton 2007; Mayer et al. 2007). Because riparian soils, geomorphology, hydrologic flowpaths, and geology all play roles in explaining 
variations in denitrification rates (e.g. Alexander et al. 2000, Stanley and Doyle 2002, Groffman and Crawford 2003, Gücker and Boechat 2004, Wollheim et al. 2005), all of these factors should be considered and further evaluated in the efficacy of restoration designs aimed at increasing both denitrification rates and mass removal of nitrate- $\mathrm{N}$ in riparian zones.

Restoration practices that improve connectivity between the stream and the riparian zone can increase $\mathrm{NO}_{3}{ }^{-}$removal. Yet, more work is necessary to better quantify the effectiveness of stream restoration practices under various applications and conditions and over time (Stanley and Doyle 2002, Kasahara and Hill 2006, Bukaveckas 2007, Roberts et al. 2007). For example, little is known about how $\mathrm{N}$ removal is affected by changes in riparian plant communities, changes in soil organic matter, or variable stormwater flows and discharge. Furthermore, urban watersheds may behave differently than streams in less developed watersheds which have been more thoroughly studied (e.g. Peterson et al. 2001, Mulholland et al. 2004, Kaushal and Lewis 2005; Doheny and Baker 2018). Comparisons of streams in other regions and land use types will be critical in determining effectiveness of restoration and establishment of metrics to assess water quality improvements associated with stream and riparian restoration.

Our seasonal measures of surface water $\mathrm{N}$ and $\mathrm{DO}$ at Minebank Run suggest that $\mathrm{N}$ management is more difficult in winter when temperatures are lower, inhibiting microbial activity and sustaining more DO in water, thereby inhibiting anaerobic conditions favoring denitrification (Dawson and Murphy 1972; Tiedje et al. 1982; llies and Mavinic 2001; Kadlec and Reddy 2001).

Based on long term $\mathrm{N}$ patterns at the BES LTER sites, integrating restoration approaches with stormwater management to slow the flow of water may be critical to maximizing $\mathrm{N}$ removal. However, performance among restoration designs and hydrologic conditions is likely to be highly variable, suggesting that stream restoration by itself is currently not adequate to mitigate for excess $\mathrm{N}$ inputs or to compensate for stream destruction and degradation (Craig et al. 2008) and that a comprehensive approach must be taken for watershed management (USEPA 2008) including reducing effective impervious surface coverage in uplands (Walsh et al. 2005) and repairing aging infrastructure (Doyle et al. 2008). The lack of stormwater management in the Minebank Run watershed may have contributed to failure of the restoration and, therefore, a combination of restoration features and stormwater management (Reisinger et al. 2019) may improve long-term efficacy of restoration.

Minebank Run is one of thousands of streams leading to the Chesapeake Bay representing about $5.2 \mathrm{~km}$ of stream length of the estimated $160,000 \mathrm{~km}$ of streams within the $166,000 \mathrm{~km}^{2}$ watershed of the Chesapeake Bay (USEPA 2009). Total cost of restoration at Minebank Run was \$4.4 million (in 2005 US\$; Baltimore County Department of Environmental Protection and Sustainability, unpublished). Employing this type of restoration solely for managing $\mathrm{N}$ is prohibitively expensive and likely will not address the impacts of future $\mathrm{N}$ loads and sources. While stream restoration is not the primary solution to $\mathrm{N}$ management in Chesapeake Bay, stream restoration has numerous cumulative, potential benefits that may justify the costs of such efforts, including, sediment and erosion control, protection of property, 
increased property values, fish and wildlife habitat and migration corridors, green space, stream temperature control, improved ecosystem metabolism and maintenance of riparian zones.

Longevity or efficacy of restoration projects, especially under repeated storm effects or increasing urbanization, or from the effects of salinization and chemical cocktails (Cooper et al. 2014, Kaushal et al. 2020), is currently unknown. Storms after the restoration may have exceeded the channel design discharge for which the restoration at Minebank Run was engineered and/or the bankfull dimensions may have been too difficult to accurately identify (Sortman 2004). Soil instability and poor vegetation reestablishment also may lead to erosion during overbank flows (Sortman 2004). Natural channel design (NCD) restoration approaches integrate fluvial processes of "self-formed and self-maintained natural rivers" (Rosgen 2011). Because urban streams self-form in highly altered landscapes, applying NCD techniques in effort to reconstruct a stable reference reach yields unexpected outcomes and the geomorphologic evolution of such restored streams has not been fully documented. While NCD may produce a more functional stream in the sense of flashiness or nutrient uptake, metrics of success and failure have not yet been fully established and protocols for stream restoration intended to reduce $\mathrm{N}$ transport are evolving (Urban Stormwater Work Group 2020). Furthermore, ecosystem functions in urban streams such as nutrient uptake may be more resilient to disturbance, storm events, and floods because of functional redundancy of the microbial communities driving processes such as denitrification (Utz et al. 2016; Reisinger et al. 2017). Future studies should investigate effects of varying $N$ loads, hydrologic residence times, hydrological connectivity, and seasonality on denitrification rates in restored streams and under different land uses and stream flow conditions (e.g. Tague et al. 2008). Further research on coupled restoration practices with stormwater management may be useful because it may be desirable to create conditions with high denitrification rates in urban areas where water from the landscape is concentrated (Pennino et al. 2016).

Restoration designs are heterogeneous efforts consisting of various components including bank reshaping, bank stabilization, channel reconstruction, riparian re-vegetation, etc. Therefore, study designs that distinguish the influence of individual restoration components will help to identify those techniques that contribute most to nutrient uptake and other ecosystem functions of concern. Also, because in situ $\mathrm{N}$ uptake and transformation is notoriously difficult to measure (Groffman et al. 2006), studies that measure denitrification or surrogates of denitrification (e.g. oxidation-reduction potential, DO) at watershed scales and over time will be most useful in quantifying restoration effects. Finally, long-term monitoring will better elucidate short and long-term patterns of nutrient dynamics (Goodale et al. 2003, Goodale et al. 2005, White et al. In Prep). Therefore, long-term studies like this and the BES LTER (Pickett et al. 2001, Cadenasso et al. 2008, Mayer et al. 2010a) are critical for understanding restoration effectiveness.

\section{Declarations}

Funding - Research funding was provided by U.S. Environmental Protection Agency (EPA), Office of Research and Development to US Geological Survey through Interagency Agreement DW-14-93944801-0. 
Conflicts of interest/Competing interests - no conflicts of interest or competing interests to declare

Ethics approval - Not applicable

Consent to participate - Not applicable

Consent for publication - All authors have consented to publication

\section{Availability of data and material (data transparency)}

\section{Code availability (software application or custom code)}

\section{Acknowledgments}

We thank Kathy Bates, Lynda Callaway, Jon Dillow, Kenneth Jewell, Mastin Mount, Russell Neill, and Roger Starsoneck for assistance in the field and lab. Edward Doheny collected surface water samples, maintained the USGS stream gage at our study site, provided technical review of our manuscript, and provided invaluable logistics assistance. Robert Shedlock helped design the study, provided invaluable research insights, and improved earlier drafts of the manuscript. Elise Striz established the well network and provided critical guidance on study design. Katherine Loizos created restoration figures. We are grateful for the cooperation and assistance of Baltimore County Department of Environmental Protection and Resource Management and to Baltimore County Parks and Recreation for site access. Peter Groffman kindly provided logistical support at the Baltimore Ecosystem Study Long-Term Ecological Research site, and we are grateful for his continued support over the years. This research benefited greatly from keen insights, thoughtful contributions, and unwavering support from long-time collaborator, Sujay Kaushal. This document has been reviewed in accordance with U.S. Environmental Protection Agency policy and approved for publication. Any mention of trade names, manufacturers or products does not imply an endorsement by the United States Government or the U.S. Environmental Protection Agency. EPA and its employees do not endorse any commercial products, services, or enterprises.

\section{References}

1. Alexander RB, Smith RA, Schwarz GE (2000) Effect of stream channel size on the delivery of nitrogen to the Gulf of Mexico. Nature 403:758-761.

2. Altman SJ, Parizek RR (1995) Dilution of nonpoint-source nitrate in ground water. J. Environmental Quality 24:707-718.

3. APHA (1998) Standard Methods for the Examination of Water and Wastewater, 20th ed. American Public Health Association, Washington, DC.

4. Baker DB, Richards RP, Loftus TT, Kramer JW (2004) A new flashiness index: Characteristics and applications to midwestern rivers and streams. Journal of the American Water Resources Association 40:503-522. 
5. Baker MA, Valett HM, Dahm CN (2000) Organic carbon supply and metabolism in a shallow ground water ecosystem. Ecology 81:3133-3148.

6. Beaulieu JJ, Golden HE, Knightes CD, Mayer PM, Kaushal SS, Pennino MJ, Arango CP, Balz DA, Elonen CM, Fritz KM, Hill BH (2015) Urban stream burial increases watershed scale nitrate export. PLoS One July 17, 2015; DOI: 10.1371/journal.pone.0132256

7. Beaulieu JJ, PM Mayer, SS Kaushal, MJ Pennino, CP Arango, DA Balz, TJ Canfield, CM Elonen, KM Fritz, BH Hill, H Ryu, JW Santo Domingo (2014) Effects of urban stream burial on organic matter dynamics and reach scale nitrate retention. Biogeochemistry DOI 10.1007/s10533-014-9971-4

8. Bernhardt ES, Hall RO, Likens GE (2002) Whole-system estimates of nitrification and nitrate uptake in streams of the Hubbard Brook Experimental Forest. Ecosystems 5:419-430.

9. Bernhardt ES, Likens GE (2002) Dissolved organic carbon enrichment alters nitrogen dynamics in a forest stream. Ecology 83:1689-1700.

10. Bernhardt ES, Palmer MA, Allan JD, Alexander G, Barnas K, Brooks S, Carr J, Clayton S, Dahm C, Follstad-Shah J, Galat D, Gloss S, Goodwin P, Hart D, Hassett B, Jenkinson R, Katz S, Kondolf GM, Lake PS, Lave R, Meyer JL, O’Donnell TK, Pagano L, Powell B, Sudduth E (2005) Synthesizing U.S. river restoration efforts. Science 308:636-637.

11. Boulton AJ (2007) Hyporheic rehabilitation in rivers: restoring vertical connectivity. Freshwater Biology 52:632-650.

12. Bukaveckas PA (2007) Effects of channel restoration on water velocity, transient storage, and nutrient uptake in a channelized stream. Environmental Science and Technology 41:1570-1576.

13. Cadenasso ML, Pickett STA, Groffman PM, Band LE, Brush GS, Galvin MF, Grove JM, Hager GW, Marshall V, McGrath BP, O'Neil-Dunne JPM, Stack WP, Troy AR (2008) Exchanges across land-waterscape boundaries in urban systems: strategies for reducing nitrate pollution. Annals of the New York Academy of Sciences Volume: 1134 213- 232.

14. Cooper CA, Mayer PM, Faulkner BR (2014). Effects of road salts on groundwater and surface water dynamics of sodium and chloride in an urban restored stream. Biogeochemistry 121:149-166

15. Craig LS, Palmer MA, Richardson DC, Filoso S, Bernhardt ES, Bledsoe BP, Doyle MW, Groffman PM, Hassett BA, Kaushal SS, Mayer PM, Smith SM, Wilcock PR (2008) Stream restoration strategies for reducing river nitrogen loads. Frontiers in Ecology and the Environment 6:529-538.

16. Dawson RN Murphy KL (1972) The temperature dependency of biological denitrification. Water Research. 6:71-83.

17. Doheny EJ, Baker SM (2018) Geomorphic characteristics of Tenmile Creek, Montgomery County, Maryland, 2014-16: U.S. Geological Survey Scientific Investigations Report 2018-5098, 34 p., https://doi.org/10.3133/sir20185098

18. Doheny EJ, Dillow JJA, Mayer PM, Striz EA (2012) Geomorphic responses to stream channel restoration at Minebank Run, Baltimore County, Maryland, 2002-08: U.S. Geological Survey Scientific Investigations Report 2012-5012, 61 p. http://pubs.usgs.gov/sir/2012/5012/ 
19. Doheny EJ, Starsoneck RJ, Mayer PM, Striz EA (2007) Pre-restoration geomorphic characteristics of Minebank Run, Baltimore County, Maryland, 2002-04. USGS Scientific Investigations Report 20075127.

20. Doheny EJ, Starsoneck RJ, Striz EA, Mayer PM (2006) Watershed characteristics and pre-restoration surface-water hydrology of Minebank Run, Baltimore County, Maryland, water years 2002-04: U.S. Geological Survey Scientific Investigations Report 2006-5179, 42 p.

21. Doyle MW, Stanley EH, Havlick DG, Kaiser MJ, Steinbach G, Graf WL, Galloway GE, Riggsbee JA (2008) Aging Infrastructure and Ecosystem Restoration. Science 319:286-287.

22. Duan S, Mayer P, Kaushal S, Wessel B, Johnson T (2019) Regenerative stormwater conveyance (RSC) as a restoration approach to nutrient management may depend upon carbon quantity, quality, and source. Science of the Total Environment 652:134-146.

23. Duerksen C, Snyder C (2005) Nature-Friendly Communities: Habitat Protection and Land Use Planning. Washington, D.C.: Island Press. 421 pp.

24. Eshleman KN, RD Sabo, KM Kline (2013) Surface Water Quality Is Improving due to Declining Atmospheric N Deposition. Environmental Science and Technology dx.doi.org/10.1021/es4028748

25. Fellows CS, Valett HM, Dahm CN (2001) Whole-stream metabolism in two montane streams: Contribution of the hyporheic zone Limnology and Oceanography 46:523-531.

26. Fennessy MS, Cronk JK (1997) The effectiveness and restoration potential of riparian ecotones for the management of nonpoint source pollution, particularly nitrate, Crit. Rev. Env. Sci. Tec., 27:285317.

27. Filoso S, MA Palmer (2011) Assessing stream restoration effectiveness at reducing nitrogen

28. export to downstream waters. Ecological Applications 21:1989-2006.

29. Filoso S, SMC Smith, MR Williams, MA Palmer (2015) The efficacy of constructed stream-wetland complexes at reducing the flux of suspended solids to Chesapeake Bay. Environmental Science and Technology 49:8986-8994. DOI: 10.1021/acs.est.5b00063

30. Fink DF, Mitsch WJ (2007) Hydrology and nutrient biogeochemistry in a created river diversion oxbow wetland. Ecological Engineering 30:93-102.

31. Fisher H, Kloep F, Wilzceki S, Pusch MT (2005) A river's liver - microbial processes within the hyporheic zone of a large lowland river. Biogeochemistry 76:349-371.

32. Gift D M, PM Groffman, SS Kaushal, PM Mayer (2010) Root biomass, organic matter and denitrification potential in degraded and restored urban riparian zones. Restoration Ecology 18:113120.

33. Goodale LC, Aber JD, Vitousek PM (2003) An unexpected nitrate decline in New Hampshire streams. Ecosystems 6:75-86.

34. Goodale LC, Aber JD, Vitousek PM, McDowell WH (2005) Long-term decreases in stream nitrate: successional causes unlikely; possible links to DOC? Ecosystems 8:334-337. 
35. Grant SB, M Azizian, P Cook, F Boano, MA Rippy (2018) Factoring stream turbulence into global assessments of nitrogen pollution. Science 359:1266-1269.

36. Groffman PM, Altabet MA, Böhlke JK, Butterbach-Bahl K, David MB, Firestone MK, Giblin AE, Kana TM, Nielsen LP, Voytek MA (2006) Methods for measuring denitrification: Diverse approaches to a difficult problem. Ecological Applications 16:2091-2122.

37. Groffman, PM, Bain DJ, Band LE, Belt, KT, Brush GS, Grove JM, Pouyat RV, Yesilonis IC, and Zipperer WC (2003) Down by the riverside: urban riparian ecology. Frontiers in Ecology and the Environment 6:315-321.

38. Groffman PM, Boulware NJ, Zipperer WC, Pouyat RV, Band LE, Colosimo MF (2002) Soil nitrogen cycling processes in urban riparian zones. Environmental Science \& Technology 36:4547-4552.

39. Groffman PM, Crawford MK (2003) Denitrification potential in urban riparian zones. J. Environmental Quality 32:1144-1149.

40. Groffman PM, Dorsey AM, Mayer PM (2005) N processing within geomorphic structures in urban streams. J North American Benthological Society 24:613-625.

41. Gücker B, Boechat IG (2004) Stream morphology controls ammonium retention in tropical headwaters. Ecology 85:2818-2827.

42. Hammersmark C T, Rains MC, Mount JF (2008) Quantifying the hydrological effects of stream restoration in a montane meadow, northern California, USA. River Research and Applications 24:735753.

43. Harrison MD, Groffman PM, Mayer PM, Kaushal SS, Newcomer TA. 2011. Denitrification in alluvial wetlands in an urban landscape. Journal of Environmental Quality 40:634-646.

44. Harrison MD, Groffman PM, Mayer PM, Kaushal SS (2012a) Nitrate removal in two relict oxbow urban wetlands: A 15N mass-balance approach. Biogeochemistry 111:647-660.

45. Harrison MD, Groffman PM, PM Mayer PM, SS Kaushal SS (2012b) Microbial biomass and activity in geomorphic features in forested and urban restored and degraded streams. Ecological Engineering 38:1-10.

46. Harrison MD, Miller AJ, Groffman PM, PM Mayer PM, SS Kaushal SS (2014) Hydrologic controls on nitrogen and phosphorous dynamics in relict wetlands adjacent to an urban restored stream. Journal of the American Water Resources Association 50:1365-1382.

47. Hassett B, Palmer M, Bernhardt E, Smith S, Carr J, Hart D (2005) Restoring watersheds project by project: Trends in Chesapeake Bay tributary restoration. Frontiers in Ecology and the Environment 3:259-267.

48. Hedin LO, von Fischer JC, Ostrom NE, Kennedy BP, Brown MG, Robertson GP (1998) Thermodynamic constraints on nitrogen transformations and other biogeochemical processes at soil-stream interfaces. Ecology 79:684-703.

49. Hill AR, Labadia CF, Sanmugadask K (1998) Hyporheic zone hydrology and nitrogen dynamics in relation to the streambed topography of a $\mathrm{N}$ rich stream. Biogeochemistry $42: 285-310$. 
50. Hirsch, RM, De Cicco LA (2015) User Guide to Exploration and Graphics for RivEr Trends (EGRET) and data Retrieval: R Packages for Hydrologic Data, USGS. Chapter 10 of Section A, Statistical Analysis, Book 4, Hydrologic Analysis and Interpretation, Techniques and Methods 4-A10, Version 2.0, February 2015, U.S.

51. Hirsch, RM, Moyer DL, Archfield SA (2010) Weighted regressions on time, discharge, and season (WRTDS), with an application to Chesapeake Bay river inputs 1. Journal of the American Water Resources Association 46:857-880.

52. Hudson, PF, Heitmuller FT, Leitch MB (2012) Hydrologic connectivity of oxbow lakes along the lower Guadalupe River, Texas: The influence of geomorphic and climatic controls on the "flood pulse concept". Journal of Hydrology 414:174-183.

53. Ilies P, Mavinic DS (2001) The effect of decreased ambient temperature on the biological nitrification and denitrification of a high ammonia landfill leachate. Water Research 35:2065-2072.

54. Jacobson, RB, Lindner G, Bitner C (2015) The role of floodplain restoration in mitigating flood risk, Lower Missouri River, USA. Pages 203-243 in "Geomorphic approaches to integrated floodplain management of lowland fluvial systems in North America and Europe”, Paul F. Hudson and Hans Middlekoop eds. Springer

55. Jones Jr JB, Holmes RM (1996) Surface-subsurface interaction in stream ecosystems. Trends in Ecology and Evolution 11:239-242.

56. Kadlec RH, Reddy KR (2001) Temperature effects in treatment wetlands. Water Environment Research 73:543-557.

57. Kasahara T, Hill AR (2006) Hyporheic exchange flows induced by constructed riffles and steps in lowland streams in southern Ontario, Canada. Hydrological Processes 20:4287-4305.

58. Kaushal SS, Belt KT (2012) The urban watershed continuum: evolving spatial and temporal dimensions. Urban Ecosystems 15:409-435.

59. Kaushal SS, Groffman PM, Mayer PM, Striz EA, Doheny EJ, Gold AJ (2008a) Effects of stream restoration on denitrification at the riparian-stream interface of an urbanizing watershed of the midAtlantic U.S. Ecological Applications 18:789-804.

60. Kaushal SS, Lewis Jr WM (2005) Transport and fate of dissolved organic nitrogen in minimally disturbed streams. Biogeochemistry 74:303-321.

61. Kaushal SS, Wood KL, Galella JG, Giona AM, Haq S, Goodling PJ, Haviland KA, Reimer JE, Morel CJ, Wessel B, Nguyen W, Hollingsworth JW, Mei K, Leal J, Widmer J, Sharif R, Mayer PM, Newcomer Johnson TA, Newcomb KD, Smith E, Belt KT (2020) Making urban 'chemical cocktails' - Evolving geochemical processes across the Periodic Table of elements. Applied Geochemistry https://doi.org/10.1016/j.apgeochem.2020.104632

62. Kaye JP, Groffman PM, Grimm NB, Baker LA, Pouyat RV (2006) A distinct urban biogeochemistry? Trends in ecology and evolution 21:192-199.

63. Kemp MJ, Dodds WK (2002) The influence of ammonium, nitrate, and dissolved oxygen concentrations on uptake, nitrification, and denitrification rates associated with prairie stream 
substrata. Limnology and Oceanography 47:1380-1393.

64. Klocker CA, Kaushal SS, Groffman PM, Mayer PM, Morgan RP (2009) Nitrogen uptake and denitrification in a restored urban stream. Aquatic Sciences 71:411-424.

65. Konrad CP, Booth DB, Burges SJ (2005) Effects of urban development in the Puget Lowland, Washington, on interannual streamflow patterns: Consequences for channel form and streambed disturbance. Water Resources Research 41, W07009, doi:10.1029/2005WR004097.

66. Lazar JG, Gold AJ, Addy K, Mayer PM, Forshay KJ, Groffman PM (2014) Instream large wood: Denitrification hotspots with low $\mathrm{N}_{2} \mathrm{O}$ production. Journal of the American Water Resources Association 50:615-625

67. Linker LC, Dennis R, Shenk GW, Batiuk RA, Grimm J, Wang P (2013) Computing atmospheric nutrient loads to the Chesapeake Bay watershed and tidal waters. Journal of the American Water Resources Association 1-17. DOI: 10.1111/jawr.12112

68. Loperfido JV, Noe GB, Jarnagin ST, Hogan DM (2014) Effects of distributed and centralized stormwater best management practices and land cover on urban stream hydrology at the catchment scale." Journal of Hydrology 519:2584-2595.

69. Lovett GM, Trayno MM, Pouyat RV, Carreiro MM, Zhu W-X, Baxter JW (2000) Atmospheric Deposition to Oak Forests along an Urban-Rural Gradient. Environmental Science and Technology 34:42944300.

70. Mayer P, Grimm N, Lepczyk C, Pickett S, Pouyat R, Warren P (2010a) Urban ecosystems research joins mainstream ecology. Nature 467:153 doi:10.1038/467153b

71. Mayer PM, Groffman PM, Striz E, Kaushal SS (2010b) Nitrogen dynamics at the ground watersurface water interface of a degraded urban stream. Journal of Environmental Quality 39:810-823.

72. Mayer PM, Reynolds SK, McCutchen MD, Canfield TJ (2007) Meta-analysis of nitrogen removal in riparian buffers. Journal of Environmental Quality 36:1172-1180.

73. Mayer PM, Schechter SP, Kaushal SS, Groffman PM (2013) Effects of stream restoration on nitrogen removal and transformation in urban watersheds: Lessons from Minebank Run, Baltimore, Maryland. Watershed Science Bulletin (Spring) Vol. 4, Issue 1, online: https://www.cwp.org/watershed-science-bulletin-past-issues/

74. Mayer PM, Striz E, Shedlock R, Doheny, Groffman P (2003) The effects of ecosystem restoration on nitrogen processing in an urban mid-Atlantic piedmont stream. Pp. 536-541 in Renard, Kenneth G., McElroy, Stephen A., Gburek, William J., Canfield, H. Evan and Scott, Russell L., eds. First Interagency Conference on Research in the Watersheds, October 27-30, 2003. U.S. Department of Agriculture, Agricultural Research Service.

75. McClain ME, Boyer EW, Dent CL, Gergel SE, Grimm NB, Groffman PM, Hart SC, Harvey JW, Johnston CA, Mayorga E, McDowell WH, Pinay G (2003). Biogeochemical hot spots and hot moments at the interface of terrestrial and aquatic ecosystems. Ecosystems 6:301-312.

76. Medalie L, Hirsch RM, Archfield SA (2012) Use of flow-normalization to evaluate nutrient concentration and flux changes in Lake Champlain tributaries, 1990-2009. Journal of Great Lakes 
Research 38:58-67.

77. Meierdiercks KL, Smith JA, Baeck ML, Miller AJ (2010) Analyses of urban drainage network structure and its impact on hydrologic response. Journal of the American Water Resources Association 46:932-943.

78. Mulholland PJ, Valett HM, Webster JR, Thomas SA, Cooper LW, Hamilton S, Peterson BJ. 2004. Stream denitrification and total nitrate uptake lengths measured using $15 \mathrm{~N}$ tracer addition approach. Limnology \& Oceanography 49:809-820.

79. Munn NL, Meyer JL (1990) Habitat-specific solute retention in two small streams: an intersite comparison. Ecology 71:2069-2082.

80. Newcomer TA, SS Kaushal, PM Mayer, AR Shields, EA Canuel, PM Groffman, AJ Gold (2012) Influence of natural \& novel organic carbon sources on denitrification in forested, degraded-urban, \& restored streams. Ecological Monographs 82:449-466.

81. Newcomer-Johnson T, Kaushal SS, Mayer PM, Smith R, Sivirichi G (2016) Nutrient Retention in Restored Streams and Rivers: A Global Review and Synthesis. Water 8 (4), 116; doi:10.3390/w8040116

82. Palmer M (2009) Reforming watershed restoration: Science in need of application

83. and applications in need of science. Estuaries \& Coasts. DOI 10.1007/s12237-008-9129-5.

84. Palmer MA, Filoso S, Fanelli RM (2014) From ecosystems to ecosystem services: Stream restoration as ecological engineering. Ecological Engineering 65:62-70.

85. Paul MJ, Meyer JL (2001) Streams in the urban landscape. Annual Review of Ecology and Systematics 32:333-365.

86. Pennino MJ, Kaushal SS, Beaulieu JJ, Mayer PM, Arango CP (2014) Effects of urban stream burial on nitrogen uptake and ecosystem metabolism: implications for watershed nitrogen and carbon fluxes. Biogeochemistry DOI 10.1007/s10533-014-9958-1

87. Pennino MJ, Kaushal SS, Mayer PM, Utz RM, Cooper CA (2016) Stream restoration and sewers impact sources and fluxes of water, carbon, and nutrients in urban watersheds, Hydrology and Earth System Sciences 20:3419-3439. doi:10.5194/hess-20-3419-2016

88. Peterson BJ, Wollheim WM, Mulholland PJ, Webster JR, Meyer JL, Tank JL, Marti E, Bowden WB, Valett HM, Hershey AE, McDowell WH, Dodds WK, Hamilton SK, Gregory S, Morrall DD (2001) Control of nitrogen export from watersheds by headwater streams. Science 292:86-90.

89. Pickett STA, Cadenasso ML, Grove JM, Nilon CH, Pouyat RV, Zipperer WC, Costanza R (2001) Urban ecological systems: linking terrestrial ecological, physical, and socioeconomic components of metropolitan areas. Annual Review of Ecology and Systematics 32:127-157.

90. Poff NL, Bledsoe BP, Cuhaciyan CO (2006) Hydrologic variation with land use across the contiguous United States: Geomorphic and ecological consequences for stream ecosystems. Geomorphology 79:264-285. 
91. Puls RW, Barcelona MJ (1996) Ground Water Issue: Low-Flow (Minimal Drawdown) Ground-Water Sampling Procedures. USEPA, National Risk Management Research Lab, Ada, OK, USA. PB-97118822/XAB; EPA-540/S-95/504

92. Reisinger AJ, Rosi EJ, Bechtold HA, Doody TR, Kaushal SS, Groffman PM (2017) Recovery and resilience of urban stream metabolism following Superstorm Sandy and other floods. Ecosphere 8(4):e01776. 10.1002/ecs2.1776

93. Reisinger AJ, E Woytowitz, E Majcher, EJ Rosi, KT Belt, JM Duncan, SS Kaushal, PM Groffman (2019) Changes in long-term water quality of Baltimore streams are associated with both gray and green infrastructure. Limnology and Oceanography 64:S60-S76. doi: 10.1002/Ino.10947

94. Roberts BJ, Mulholland PJ, Houser JN (2007) Effects of upland disturbance and instream restoration on hydrodynamics and ammonium uptake in headwater streams. J North American Benthological Society 24:613-625.

95. Rosgen D (1996) Applied River Morphology. Wildland Hydrology, Pagosa Springs, CO.

96. Rosgen DL (2011) Natural Channel Design: Fundamental Concepts, Assumptions, and Methods. In A. Simon, S.J. Bennett, \& J.M. Castro (Eds.), Stream Restoration in Dynamic Fluvial Systems: Scientific Approaches, Analyses, and Tools, Geophysical Monograph Series 194, pp. 69-93. Washington, D.C.: American Geophysical Union.

97. Sholtes JS, Doyle MW (2011) Effect of Channel Restoration on Flood Wave Attenuation. Journal of Hydraulic Engineering-ASCE 137:196-208.

98. Smith BK, Smith JA, Baeck M, Villarini LG, Wright DB (2013) Spectrum of storm event hydrologic response in urban watersheds. Water Resources Research 49:2649-2663.

99. Sobczak WV, Findlay S (2002) Variation in bioavailability of dissolved organic carbon among stream hyporheic flowpaths. Ecology 83:3194-3209.

100. Sobczak WV, Findlay S, Dye S (2002) Relationships between DOC bioavailability and nitrate removal in an upland stream: An experimental approach. Biogeochemistry 62:309-327.

101. Sortman VL (2004) Complications with Urban Stream Restorations Mine Bank Run: A Case Study. ACSE publications (doi 10.1061/40695(2004)19)

102. Sudduth EB, Hassett BA, Cada P, Bernhardt ES (2011) Testing the Field of Dreams Hypothesis: functional responses to urbanization and restoration in stream ecosystems. Ecological Applications 21:1972-1988.

103. Stanley EH, Doyle MW (2002) A geomorphic perspective on nutrient retention following dam removal. BioScience 52:693-701.

104. Striz EA, Mayer PM (2008) Assessment of near-stream ground water-surface water interaction (GSI) of a degraded stream before restoration. EPA 600/R-07/058, U.S. Environmental Protection Agency, Washington, D.C.

105. Tague C, Valentine S, Kotchen M (2008) Effect of geomorphic channel 
106. restoration on streamflow and groundwater in a snowmelt-dominated watershed. Water Resources Research 44: Article Number: W10415. doi:10.1029/2007WR006418

107. Taylor PG, Townsend AR (2010) Stoichiometric control of organic carbon-nitrate relationships from soils to the sea. Nature 464:1178-1181.

108. Thompson J, Pelc CE, Brogan III WR, Jordan TE (2018) The multiscale effects of stream restoration on water quality. Ecological Engineering 124:7-18.

109. Tiedje JM, Sexstone AJ, Myrold DD, Robinson JA (1982) Denitrification: ecological niches, competition and survival. Antonie van Leeuwenhoek 48:569-583.

110. Underwood AJ (1992) Beyond BACl: the detection of environmental impacts on populations in the real, but variable, world. Journal of Experimental Marine Biology and Ecology 161:145-178.

111. Urban Stormwater Work Group (Altland D, Becraft C, Berg J, Burch J, Clearwater D, Crawford S, Doll B, Geratz J, Hanson J, Hartranft J, Hottenstein J, Kaushal S, Lowe S, Mayer P, Noe G, Scott D, Stack B) (2020) Consensus Recommendations for Improving Protocols 2 and 3 on Effect of Stream and Floodplain Restoration Projects Built for Pollutant Removal Credit. Chesapeake Bay Program. 93 pp. https://www.chesapeakebay.net/documents/FINAL_Approved_Group_4_Memo_10.27.20.pdf

112. USEPA (1983) Methods for chemical analysis of water and wastes. United States Environmental Protection Agency, EPA 841-B-08-002. Washington, DC.

113. USEPA (2006) Baltimore County Stream Restoration Improves Quality of Life. EPA/903/F-06/008. Ft. Meade, MD

114. USEPA (2008) Handbook for Developing Watershed Plans to Restore and Protect Our Waters. EPA600/4-79-020. Cincinnati OH.

115. USEPA (2009) Bay Barometer: A health and restoration assessment of the Chesapeake Bay and Watershed in 2008. EPA-903-R-09-001, Chesapeake Bay Program.

116. Utz RM, Hopkins KG, Beesley L, Booth DB, Hawley RJ, Baker ME, Freeman MC, Jones KL (2016) Ecological resistance in urban streams: the role of natural and legacy attributes. Freshwater Science 35:380-397.

117. Vidon P, Allan C, Burns D, Duval TP, Gurwick N, Inamdar S, Lowrance R, Okay J, Scott D, Sebestyen S (2010) Hot spots and hot moments in riparian zones: Potential for improved water quality management. Journal of the American Water Resources Association 1-21. DOI: 10.1111 / j.17521688.2010.00420.x

118. Violin CR, Cada P, Sudduth EB, Hassett BA, Penrose DL, Bernhardt ES (2011) Effects of urbanization and urban stream restoration on the physical and biological structure of stream ecosystems. Ecological Applications 21:1932-1949.

119. Walsh CJ, Roy AH, Feminella JW, Cottingham PD, Groffman PM, Morgan II RP (2005) The urban stream syndrome: current knowledge and the search for a cure. J North American Benthological Society 24:706-723.

120. White DP, Newcomer-Johnson TN, et al. (In prep). A review of habitat restoration projects across Great Lakes Areas of Concern: Variability in actions, goals, monitoring, and outcomes. 
121. Wollheim WM, Pellerin BA, Vörösmarty CJ, Hopkinson CS (2005) N retention in urbanizing headwater catchments. Ecosystems 8:871-884.

122. Woltemade CJ, Potter KW (1994) A watershed modeling analysis of fluvial geomorphologic influences on flood peak attenuation. Water Resources Research 30:1933-1942.

123. Wood KL, Kaushal SS, Vidon PG, Mayer PM, Galella JG. Tree trade-offs in stream restoration projects: impact on riparian groundwater quality. This issue

\section{Tables}

Table 1. ANOVA comparisons of nitrate $\left(\mathrm{NO}_{3}{ }^{-}\right)$, dissolved organic carbon (DOC), and chloride $\left(\mathrm{Cl}^{-}\right)$ concentrations $(\mathrm{mg} / \mathrm{L})$ in groundwater versus surface water at restored CVP and control Intervale sites during pre- and post-restoration time periods*. Table shows sample size $(\mathrm{N})$, mean $(\overline{\mathbf{x}})$, standard error $(\mathrm{SE})$, degrees freedom (df), $F$ statistics $(\mathrm{F})$, and $p$-values $(p)$. Statistical comparisons $(d f, F, p)$ represent a comparison of groundwater vs. surface water at each site during each time period. * Six outliers $\left(\mathrm{NO}_{3}{ }^{-}>6\right.$ $\mathrm{mg} / \mathrm{L})$ excluded from $\mathrm{NO}_{3}{ }^{-}$analyses. ${ }^{*}$ One outlier $\left(\mathrm{Cl}^{-}>400 \mathrm{mg} / \mathrm{L}\right)$ excluded from $\mathrm{Cl}^{-}$analyses.

\begin{tabular}{|c|c|c|c|c|c|c|c|c|c|c|c|c|c|c|c|c|c|c|c|c|c|}
\hline & & & & \multicolumn{6}{|c|}{$\mathrm{NO}_{3}^{-}$} & \multicolumn{6}{|c|}{$\mathrm{DOC}$} & \multicolumn{6}{|c|}{$\mathrm{Cl}^{-}$} \\
\hline treatment & time period & $\underline{\text { Site }}$ & GW/SW & $\underline{\mathrm{N}}$ & mean & $\underline{\mathrm{SE}}$ & $d f$ & $F$ & $\underline{p}$ & $\underline{N}$ & mean & $\underline{\mathrm{SE}}$ & $d f$ & $\underline{F}$ & $\underline{p}$ & $\underline{\mathrm{N}}$ & mean & SE & $d f$ & $F$ & $\underline{p}$ \\
\hline \multirow{2}{*}{ restored } & \multirow{2}{*}{ pre-restoration } & \multirow{2}{*}{ CVP } & GW & 122 & 1.55 & $\overline{0.08}$ & \multirow{2}{*}{1,135} & \multirow{2}{*}{0.05} & \multirow{2}{*}{0.8} & 122 & 0.77 & 0.04 & \multirow{2}{*}{1,135} & \multirow{2}{*}{60.8} & \multirow{2}{*}{$<0.001$} & 122 & 122.6 & 6.02 & \multirow[b]{2}{*}{1,135} & \multirow{2}{*}{2.38} & \multirow{2}{*}{0.13} \\
\hline & & & SW & 15 & 1.61 & 0.03 & & & & 15 & 1.78 & 0.16 & & & & 15 & 150.2 & 14.15 & & & \\
\hline \multirow{2}{*}{ restored } & \multirow{2}{*}{ post-restoration } & \multirow{2}{*}{ CVP } & GW & $291^{*}$ & 1.28 & 0.06 & \multirow{2}{*}{1,332} & \multirow{2}{*}{1.67} & \multirow{2}{*}{0.2} & 297 & 0.79 & 0.03 & \multirow{2}{*}{1,338} & \multirow{2}{*}{135.8} & \multirow{2}{*}{$<0.001$} & 297 & 130.2 & 4.96 & \multirow{2}{*}{1,338} & \multirow{2}{*}{0.19} & \multirow{2}{*}{0.7} \\
\hline & & & SW & 43 & 1.08 & 0.07 & & & & 43 & 1.69 & 0.09 & & & & 43 & 124.5 & 4.19 & & & \\
\hline \multirow{2}{*}{ control } & \multirow{2}{*}{ pre-restoration } & \multirow{2}{*}{ Intervale } & $\mathrm{GW}$ & 27 & 0.84 & 0.06 & \multirow{2}{*}{1,33} & \multirow{2}{*}{0.09} & \multirow{2}{*}{0.8} & 27 & 0.52 & 0.07 & 133 & 602 & $<0001$ & $26^{*}$ & 35.3 & 3.60 & & 1604 & 0.001 - \\
\hline & & & SW & 8 & 0.88 & 0.10 & & & & 8 & 1.95 & 0.21 & & 09.2 & $<0.001$ & 8 & 77.2 & 15.15 & 1,32 & 10.04 & $<0.001$ \\
\hline control & nost-restoration & Intervale & GW & 168 & 0.97 & 0.04 & 1.106 & 203 & $000 \quad-\quad$ & 168 & 0.31 & 0.02 & 1.106 & 2202 & $<0001$ & 168 & 31.2 & 0.36 & 106 & 2421 & $C 00$ \\
\hline & & & SW & 30 & 1.12 & 0.06 & & & 0.09 & 30 & 1.62 & 0.18 & & & $<0.001$ & 30 & 64.3 & 4.66 & 1,190 & 242.1 & $<0.001$ \\
\hline
\end{tabular}

Table 2. ANOVA comparisons of nitrate $\left(\mathrm{NO}_{3}{ }^{-}\right)$, dissolved organic carbon (DOC), and chloride $\left(\mathrm{Cl}^{-}\right)$ concentrations $(\mathrm{mg} / \mathrm{L})$ during pre- versus post-restoration periods at restored CVP and control Intervale sites in groundwater and surface water. Table shows sample size $(\mathrm{N})$, mean $(\overline{\mathbf{x}})$, standard error (SE), degrees freedom $(\mathrm{df}), F$ statistics $(F)$, and p-values $(p)$. Statistical comparisons $(d f, F, p)$ represent a comparison of pre- vs post-restoration at each site for each type of water. ${ }^{*}$ Six outliers $\left(\mathrm{NO}_{3}{ }^{-}>6 \mathrm{mg} / \mathrm{L}\right)$ excluded from $\mathrm{NO}_{3}{ }^{-}$analyses. ${ }^{*}$ One outlier $\left(\mathrm{Cl}^{-}>400 \mathrm{mg} / \mathrm{L}\right)$ excluded from $\mathrm{Cl}^{-}$analyses.

\begin{tabular}{|c|c|c|c|c|c|c|c|c|c|c|c|c|c|c|c|c|c|c|c|c|c|}
\hline & & & & \multicolumn{6}{|c|}{$\mathrm{NO}_{3}^{-}$} & \multicolumn{6}{|c|}{$\mathrm{DOC}$} & \multicolumn{6}{|c|}{$\mathrm{Cl}$} \\
\hline treatment & time period & Site & GW/SW & $\underline{\mathrm{N}}$ & mean & $\underline{\mathrm{SE}}$ & $d f$ & $\underline{F}$ & $\underline{p}$ & $\underline{\underline{N}}$ & mean & $\underline{\mathrm{SE}}$ & $d f$ & $\underline{F}$ & $\underline{p}$ & $\underline{\mathrm{N}}$ & mean & $\underline{\mathrm{SE}}$ & $d f$ & $\underline{F}$ & $\underline{p}$ \\
\hline \multirow{2}{*}{ restored } & pre-restoration & \multirow{2}{*}{ CVP } & \multirow{2}{*}{ GW } & 122 & 1.55 & 0.08 & \multirow{2}{*}{1,411} & \multirow{2}{*}{6.72} & \multirow{2}{*}{0.01} & 122 & 0.77 & 0.04 & \multirow{2}{*}{1,417} & \multirow{2}{*}{0.19} & \multirow{2}{*}{0.7} & 122 & $\overline{122.6}$ & $\overline{6.02}$ & \multirow{2}{*}{1,417} & \multirow{2}{*}{0.77} & \multirow{2}{*}{0.4} \\
\hline & post-restoration & & & $291^{*}$ & 1.28 & 0.06 & & & & 297 & 0.79 & 0.03 & & & & 297 & 130.2 & 4.96 & & & \\
\hline \multirow{2}{*}{ restored } & pre-restoration & \multirow{2}{*}{ CVP } & \multirow{2}{*}{ SW } & 15 & 1.61 & 0.03 & \multirow{2}{*}{1,56} & \multirow{2}{*}{14.52} & \multirow{2}{*}{$<0.001$} & 15 & 1.78 & 0.16 & \multirow{2}{*}{1,56} & \multirow{2}{*}{0.23} & \multirow{2}{*}{0.6} & 15 & 150.2 & 14.15 & \multirow{2}{*}{1,56} & \multirow{2}{*}{5.61} & \multirow{2}{*}{0.02} \\
\hline & post-restoration & & & 43 & 1.08 & 0.08 & & & & 43 & 1.69 & 0.09 & & & & 43 & 124.5 & 4.19 & & & \\
\hline \multirow{2}{*}{ control } & pre-restoration & \multirow{2}{*}{ Intervale } & \multirow{2}{*}{ GW } & 27 & 0.84 & 0.06 & \multirow{2}{*}{1,193} & \multirow{2}{*}{1.84} & \multirow{2}{*}{0.2} & 27 & 0.52 & 0.07 & $1 \quad 103$ & 320 & & $26^{*}$ & 35.3 & 3.62 & 102 & & \\
\hline & post-restoration & & & 168 & 0.97 & 0.04 & & & & 168 & 0.31 & 0.02 & $f, 193$ & 13.29 & $<0.001$ & 168 & 31.2 & 0.36 & 1,192 & 0.15 & 0.01 \\
\hline Contmol & pre-restoration & Interole & SW & 8 & 0.88 & 0.10 & 36 & 335 & 00 & 8 & 1.95 & 0.21 & 136 & 0.81 & 04 & 8 & 77.2 & 15.15 & 136 & 110 & 03 \\
\hline conilitol & post-restoration & inlervale & & 30 & 1.12 & 0.06 & 1,30 & 3.35 & 0.08 & 30 & 1.62 & 0.18 & & 0.81 & 0.4 & 30 & 64.3 & 4.66 & & 1.19 & 0.3 \\
\hline
\end{tabular}


Table 3. Nitrate $\left(\mathrm{NO}_{3}{ }^{-}\right)$, dissolved organic carbon (DOC), and chloride $\left(\mathrm{Cl}^{-}\right)$concentration $(\mathrm{mg} / \mathrm{L})$ linear regression trends over time (2003-2008) in groundwater and surface water at Minebank Run*. Statistical comparisons ( $R^{2}$, regression coefficient, $p$-value) represent a comparison of pre- vs post restoration at each site for groundwater and surface water, respectively. *Six outliers $\left(\mathrm{NO}_{3}{ }^{-}>6 \mathrm{mg} / \mathrm{L}\right)$ excluded from $\mathrm{NO}_{3}{ }^{-}$analyses. ${ }^{*}$ One outlier $\left(\mathrm{Cl}^{-}>400 \mathrm{mg} / \mathrm{L}\right)$ excluded from $\mathrm{Cl}^{-}$analyses.

\begin{tabular}{|c|c|c|c|c|c|c|c|c|c|c|c|c|c|c|c|c|c|c|}
\hline & & & & \multicolumn{5}{|c|}{$\mathrm{NO}_{3}^{-}$} & \multicolumn{5}{|c|}{ DOC } & \multicolumn{5}{|c|}{$\mathrm{Cr}$} \\
\hline Treatment & Time Period & Site & GW/SW & $\mathrm{N}$ & $R^{2}$ & coefficiert & $p$-vahue & trend & $\mathrm{N}$ & $R^{2}$ & coefficient & $p$-vahue & trend & $\mathrm{N}$ & $R^{2}$ & coefficient & $p$-value & trend \\
\hline \multirow{2}{*}{ restored } & pre-restoration & \multirow{2}{*}{ CVP } & \multirow{2}{*}{ GW } & 122 & 0.003 & 0.041 & 0.6 & no trend & 122 & 0.004 & -0.027 & 0.5 & no trend & 122 & 0.099 & -18.963 & $<0.001$ & negative \\
\hline & post-restoration & & & $291^{*}$ & 0.017 & -0.048 & 0.03 & negative & 297 & 0.022 & 0.025 & 0.01 & positive & 297 & 0.016 & 4.005 & 0.03 & positive \\
\hline \multirow{2}{*}{ restored } & pre-restoration & \multirow{2}{*}{ CVP } & \multirow{2}{*}{ SW } & 15 & 0.096 & -0.035 & 0.3 & no trend & 15 & 0.006 & 0.044 & 0.8 & no trend & 15 & 0.251 & -24.493 & 0.06 & negative \\
\hline & post-restoration & & & 43 & 0.039 & -0.035 & 0.2 & no trend & 43 & 0.023 & 0.033 & 0.3 & no trend & 43 & 0.009 & -0.864 & 0.6 & no trend \\
\hline \multirow{2}{*}{ control } & pre-restoration & \multirow{2}{*}{ Intervale } & \multirow{2}{*}{ GW } & 27 & 0.039 & -0.052 & 0.3 & no trend & 27 & 0.001 & 0.008 & 0.9 & no trend & 26 & 0.042 & -3.045 & 0.3 & no trend \\
\hline & post-restoration & & & 168 & 0.002 & 0.008 & 0.6 & no trend & 168 & 0.019 & 0.014 & 0.07 & positive & 168 & 0.151 & 0.676 & $<0.001$ & positive \\
\hline \multirow{2}{*}{ control } & pre-restoration & \multirow{2}{*}{ Intervale } & \multirow{2}{*}{ SW } & 8 & 0.76 & 0.212 & 0.005 & positive & 8 & 0.586 & -0.381 & 0.03 & negative & 8 & 0.118 & 12.305 & 0.4 & no trend \\
\hline & post-restoration & & & 30 & 0.06 & -0.029 & 0.2 & no trend & 30 & 0.082 & -0.095 & 0.13 & no trend & 30 & 0.003 & -0.516 & 0.8 & no trend \\
\hline
\end{tabular}

Table 4. Linear regression trends of nitrate $\left(\mathrm{NO}_{3}{ }^{-}\right)$concentrations $(\mathrm{mg} / \mathrm{L})$ and specific conductance $(\mu \mathrm{S} / \mathrm{cm})$ over time (2003-2008) in surface water collected during bi-weekly surveys at Minebank Run. *One outlier (specific conductance $>5000 \mu \mathrm{S} / \mathrm{cm}$ ) excluded from analyses.

\begin{tabular}{|c|c|c|c|c|c|c|c|c|c|c|c|c|c|c|c|c|c|c|c|c|}
\hline \multirow[b]{2}{*}{ treatmert } & \multirow[b]{2}{*}{ Site } & \multirow[b]{2}{*}{ time period } & \multicolumn{9}{|c|}{$\mathrm{NO}_{3}^{-}(\mathrm{mgL})$} & \multicolumn{9}{|c|}{ Specific C onductance $(\mathrm{uS} / \mathrm{cm})$} \\
\hline & & & $\mathrm{N}$ & mean & $\min$ & $\max$ & $R^{2}$ & coefficient & constant & $p$-vahue & trend & $\mathrm{N}$ & mean & $\min$ & $\max$ & $R^{2}$ & coefficiert & constart & $p$-value & trend \\
\hline \multirow{3}{*}{ restored } & \multirow{3}{*}{ CVP } & pre-restoration & 76 & 1.59 & 0.23 & 4.43 & 0.42 & 0.0018 & 0.711 & $<0.001$ & positive & 75 & 896.8 & 330 & 2140 & 0.05 & 0.278 & 763.4 & 0.05 & positive \\
\hline & & construction & 27 & 1.58 & 1.10 & 2.34 & 0.25 & 0.0018 & -0.135 & 0.008 & positive & $26 *$ & 826.5 & 609 & 1027 & 0.23 & 0.647 & 221.2 & 0.01 & positive \\
\hline & & post-restoration & 170 & 1.44 & 0.57 & 2.48 & 0.08 & -0.0003 & 1.939 & $<0.001$ & negative & 170 & 945.2 & 235 & 2530 & 0.02 & 0.097 & 779.4 & 0.11 & no trend \\
\hline \multirow{2}{*}{ control } & \multirow{2}{*}{ Intervale } & construction & 28 & 1.18 & 0.77 & 2.06 & 0.36 & 0.0022 & -0.886 & 0.001 & positive & 28 & 540.3 & 353 & 1071 & 0.2 & 0.895 & -302.03 & 0.02 & positive \\
\hline & & post-restoration & 171 & 1.11 & 0.53 & 2.19 & 0.05 & -0.0002 & 1.428 & 0.005 & negative & 172 & 638.6 & 141 & 3540 & 0.004 & 0.07 & 5190.5 & 0.4 & no trend \\
\hline
\end{tabular}

Table 5. Linear regression trends of nitrate $\left(\mathrm{NO}_{3}{ }^{-}\right)$concentrations $(\mathrm{mg} / \mathrm{L})$ in surface water over time (2002-2008) among BES LTER streams. Data source:

https://portal.edirepository.org/nis/metadataviewer?packageid=knb-lter-bes.700.600; file: BES-streamchemistry-data-for-WWW-feb-2018--core-sites-only.cvs

\begin{tabular}{|c|c|c|c|c|c|c|c|c|c|c|}
\hline SiteCode & $\underline{\text { Lat }(\mathrm{N})}$ & Long. (W) & $\underline{\text { USGS gage }}$ & Site Name & category & $\underline{\mathrm{N}}$ & $\underline{R}_{-}^{2}$ & $\underline{\text { coefficient }}$ & $\underline{p}$-value & trend \\
\hline BARN & $39^{\circ} 25^{\prime} 31.9^{\prime \prime}$ & $76^{\circ} 35^{\prime} 47.4^{\prime \prime}$ & 1583800 & Baisman Run & suburban, unsewered & 371 & 0.09 & 0 & 0.07 & no trend \\
\hline DRKR & $39^{\circ} 18^{\prime} 40.4^{\prime \prime}$ & $76^{\circ} 42^{\prime} 59.9^{\prime \prime}$ & 1589330 & Dead Run & urban & 364 & 0.004 & 0 & 0.2 & no trend \\
\hline GFCP & $39^{\circ} 16^{\prime} 17.4^{\prime \prime}$ & $76^{\circ} 38^{\prime} 54.8^{\prime \prime}$ & 1589352 & Gwynns Falls at Carroll Park & urban & 363 & 0.02 & -0.001 & 0.01 & nega tive \\
\hline GFGB & $39^{\circ} 26^{\prime} 34.6^{\prime \prime}$ & $76^{\circ} 48^{\prime} 00.3 "$ & 1589197 & Gwynns Falls at Gwynnbrook Ave & suburban & 354 & 0.11 & 0.001 & 0.04 & positive \\
\hline GFGL & $39^{\circ} 28^{\prime} 18.1^{\prime \prime}$ & $76^{\circ} 49^{\prime} 00.8^{\prime \prime}$ & 1589180 & Gwynns $F$ alls at Glyndon & suburban headwaters & 332 & 0.25 & -0.001 & $<0.001$ & negative \\
\hline GFVN & $39^{\circ} 20^{\prime} 45.2^{\prime \prime}$ & $76^{\circ} 43^{\prime} 59.5^{\prime \prime}$ & 1589300 & Gwynns Falls at Villa Nova & urb an-suburb an boundary & 361 & 0.06 & 0 & 0.23 & no trend \\
\hline MCDN & $39^{\circ} 23^{\prime} 30.4^{\prime \prime}$ & $76^{\circ} 45^{\prime} 54.8^{\prime \prime}$ & 1589240 & McDonogh & agricultural & 324 & 0.79 & 0.012 & $<0.001$ & positive \\
\hline POBR & $39^{\circ} 28^{\prime} 49.1^{\prime \prime}$ & $76^{\circ} 41^{\prime} 15.0^{\prime \prime}$ & 1583570 & Pond Branch & forested reference & 361 & 0.02 & 0 & 0.7 & no trend \\
\hline
\end{tabular}

Table 6. Linear regression trends of chloride $\left(\mathrm{Cl}^{-}\right)$concentrations $(\mathrm{mg} / \mathrm{L})$ in surface water over time (2002-2008) among reference BES LTER streams. Linear regression analysis \#1 was conducted with full data set. Linear regression analysis \#2 excluded chloride outliers by limiting the data set to $<1000 \mathrm{mg} / \mathrm{L}$ at Dead Run and $<300 \mathrm{mg} / \mathrm{L}$ at the Gwynns Falls sites to exclude unusual peaks outside of overall trends. Data source: https://portal.edirepository.org/nis/metadataviewer?packageid=knb-lter- 
bes.700.600; file: BES-stream-chemistry-data-for-WWW-feb-2018--core-sites-only.cvs

\begin{tabular}{|c|c|c|c|c|c|c|c|c|c|c|c|c|c|}
\hline \multicolumn{14}{|c|}{ Anaksis \# } \\
\hline SiteCode & Lat. (N) & Long. (W) & USGS gage & Site Name & Category & $\mathrm{N}$ & $R_{-}^{2}$ & ceefficient & $\begin{array}{l}\text { standardized } \\
\text { coefficient }\end{array}$ & $R$-vahe & data range & $\begin{array}{l}\text { data points } \\
\text { exhuded }\end{array}$ & trend \\
\hline BARN & $39^{\circ} 25^{\prime} 31.9^{\prime \prime}$ & $76^{\circ} 35^{\prime} 47.4^{\prime \prime}$ & 1583800 & Baisman Run & suburban, unsewered & 371 & 0.024 & 0.002 & 0.155 & 0.003 & not limited & 0 & positive \\
\hline DRKR & $39^{\circ} 18^{\prime} 40.4^{\prime \prime}$ & $76^{\circ} 42^{\prime} 59.9^{\prime \prime}$ & 1589330 & Dead Run & urban & 355 & 0 & -0.013 & -0.009 & 0.9 & not limited & 0 & no trend \\
\hline GFCP & $39^{\circ} 16^{\prime} 17.4^{\prime \prime}$ & $76^{\circ} 38^{\prime} 54.8^{\prime \prime}$ & 1589352 & Grunns Falls at Carroll Park & urban & 358 & 0.003 & -0.019 & -0.052 & 0.3 & not limited & 0 & no trend \\
\hline GFGB & $39^{\circ} 26^{\prime} 34.6^{\prime \prime}$ & $76^{\circ} 48^{\prime} 00.3^{\prime \prime}$ & 1589197 & Gwynns Falls at Gwynnbrook Ave & suburban & 355 & 0 & -0.002 & -0.009 & 0.9 & not limited & 0 & no trend \\
\hline GFGL & $39^{\circ} 28^{\prime} 18.1^{\prime \prime}$ & $76^{\circ} 49^{\prime} 00.8^{\prime \prime}$ & 1589180 & Gwynns Falls at Glyndon & suburban headwaters & 334 & 0 & 0.002 & 0.008 & 0.9 & not limited & 0 & no trend \\
\hline GFVN & $39^{\circ} 20^{\prime} 45.2^{\prime \prime}$ & $76^{\circ} 43^{\prime} 59.5^{\prime \prime}$ & 1589300 & Gwynns Falls at Villa Nova & urban-suburban boundary & 361 & 0 & -0.006 & -0.022 & 0.7 & not limited & 0 & no trend \\
\hline MCDN & $39^{\circ} 23^{\prime} 30.4^{\prime \prime}$ & $76^{\circ} 45^{\prime} 54.8^{\prime \prime}$ & 1589240 & MkDonogh & agricultuxal & 324 & 0.06 & 0.0003 & 0.247 & $<0.001$ & not limited & 0 & positive \\
\hline POBR & $39^{\circ} 28^{\prime} 49.1^{\prime \prime}$ & $76^{\circ} 41^{\prime} 15.0^{\prime \prime}$ & 1583570 & Pond Branch & forested reference & 360 & 0.06 & 0.0001 & 0.247 & $<0.001$ & not limited & 0 & positive \\
\hline \multicolumn{14}{|c|}{ Analvsis \#2 } \\
\hline SiteCode & Lat. (N) & Long. (W) & USGS gage & Site Name & Category & $\mathrm{N}$ & $R^{2}$ & coefficient & $\frac{\text { standardized }}{\text { coefficient }}$ & $p$-vahe & data range & $\frac{\text { data points }}{\text { exchuded }}$ & trend \\
\hline BARN & $39^{\circ} 25^{\prime} 31.9^{\prime \prime}$ & $76^{\circ} 35^{\prime} 47.4^{\prime \prime}$ & 1583800 & Baisman Run & suburban, unsewered & 371 & 0.024 & 0.002 & 0.155 & 0.003 & not limited & 0 & pos itive \\
\hline DRKR & $39^{\circ} 18^{\prime} 40.4^{\prime \prime}$ & $76^{\circ} 42^{\prime} 59.9^{\prime \prime}$ & 1589330 & Dead Run & urban & 323 & 0.004 & 0.015 & 0.066 & 0.24 & $\mathrm{C} 1<1000 \mathrm{mg} / \mathrm{L}$ & 32 & no trend \\
\hline GFCP & $39^{\circ} 16^{\prime} 17.4^{\prime \prime}$ & $76^{\circ} 38^{\prime} 54.8^{\prime \prime}$ & 1589352 & Grunns Falls at Carroll Park & urban & 334 & 0.015 & 0.007 & 0.123 & 0.025 & $\mathrm{Cl}<300 \mathrm{mg} / \mathrm{L}$ & 24 & positive \\
\hline GFGB & $39^{\circ} 26^{\prime} 34.6^{\prime \prime}$ & $76^{\circ} 48^{\prime} 00.3^{\prime \prime}$ & 1589197 & Gwynns Falls at Gwynnbrook Ave & suburban & 345 & 0.054 & 0.011 & 0.232 & $<0.001$ & $\mathrm{Cl}<300 \mathrm{mg} / \mathrm{L}$ & 10 & pos itive \\
\hline GFGL & $39^{\circ} 28^{\prime} 18.1^{\prime \prime}$ & $76^{\circ} 49^{\prime} 00.8^{\prime \prime}$ & 1589180 & Gwynns Falls at Glyndon & suburban headwaters & 319 & 0.002 & 0.002 & 0.043 & 0.45 & $\mathrm{Cl}<300 \mathrm{mg} / \mathrm{L}$ & 15 & no trend \\
\hline GFVN & $39^{\circ} 20^{\prime} 45.2^{\prime \prime}$ & $76^{\circ} 43^{\prime} 59.5^{\prime \prime}$ & 1589300 & Grvynns Falls atVilla Nova & urban-suburban boundary & 341 & 0.038 & 0.011 & 0.195 & 40.001 & $\mathrm{Cl}<300 \mathrm{mg} / \mathrm{L}$ & 20 & positive \\
\hline MCDN & $39^{\circ} 23^{\prime} 30.4^{\prime \prime}$ & $76^{\circ} 45^{\prime} 54.8^{\prime \prime}$ & 1589240 & MkDonogh & agricultuxal & 324 & 0.06 & 0.0003 & 0.247 & $<0.001$ & not limited & 0 & positive \\
\hline POBR & $39^{\circ} 28^{\prime} 49.1^{\prime \prime}$ & $76^{\circ} 41^{\prime} 15.0^{\prime \prime}$ & 1583570 & Pond Branch & fore sted reference & 360 & 0.06 & 0.0001 & 0.247 & 40.001 & not limited & 0 & positive \\
\hline
\end{tabular}

Table 7. ANOVA comparisons of nitrate $\left(\mathrm{NO}_{3}{ }^{-}\right)$, dissolve organic carbon (DOC), and chloride ( $\left.\mathrm{Cl}^{-}\right)$ concentrations (mg/L) in groundwater among stream features Minebank Run. *Tukey's post-hoc tests were performed to compare means during the pre-restoration and post-restoration periods, respectively. Means with the same letter are not significantly different $p>0.05$.

\begin{tabular}{|c|c|c|c|c|c|c|c|c|c|c|c|}
\hline & & & \multicolumn{3}{|c|}{$\mathrm{NO}_{3}{ }^{-}$} & \multicolumn{3}{|c|}{$\mathrm{DOC}$} & \multicolumn{3}{|c|}{$\mathrm{Cl}$} \\
\hline time period & feature & $\underline{\mathrm{N}}$ & mean & $\underline{\mathrm{SE}}$ & post hock & mean & $\underline{\mathrm{SE}}$ & post hoc ${ }^{*}$ & mean & $\underline{\mathrm{SE}}$ & post hock \\
\hline \multirow{4}{*}{ pre-restoration } & cutbank & 22 & 2.60 & 0.30 & $\mathrm{a}$ & 0.55 & 0.12 & $\mathrm{a}$ & 59.8 & 6.3 & $\mathrm{a}$ \\
\hline & gravel bar & 33 & 0.95 & 0.09 & $\mathrm{~b}$ & 0.76 & 0.06 & $\mathrm{a}$ & 163.5 & 11.3 & $\mathrm{~b}, \mathrm{c}$ \\
\hline & stream channel & 58 & 1.53 & 0.06 & $\mathrm{c}$ & 1.18 & 0.08 & $\mathrm{~b}$ & 135.0 & 8.3 & $a, b$ \\
\hline & terrace & 24 & 1.51 & 0.08 & $\mathrm{c}$ & 0.61 & 0.05 & $\mathrm{a}$ & 111.4 & 10.3 & $\mathrm{a}$ \\
\hline \multirow{6}{*}{ post-restoration } & cutbank & 3 & 0.91 & 0.09 & $a, b$ & 0.94 & 0.07 & $a, b$ & 74.3 & 8 & $\mathrm{a}$ \\
\hline & gravel bar & 75 & 0.76 & 0.05 & $\mathrm{a}, \mathrm{c}$ & 0.98 & 0.06 & $\mathrm{~b}$ & 212.3 & 13.9 & $\mathrm{~b}$ \\
\hline & stream channel & 113 & 1.15 & 0.04 & $\mathrm{a}$ & 1.23 & 0.06 & $\mathrm{a}, \mathrm{c}$ & 128.5 & 3.3 & $\mathrm{a}, \mathrm{c}$ \\
\hline & terrace & 55 & 1.48 & 0.08 & $\mathrm{a}, \mathrm{d}$ & 0.60 & 0.05 & $\mathrm{a}$ & 99.1 & 5.2 & $\mathrm{a}$ \\
\hline & riprap & 27 & 0.64 & 0.08 & $\mathrm{a}$ & 0.51 & 0.03 & $\mathrm{a}$ & 104.3 & 8.9 & $\mathrm{a}$ \\
\hline & oxbow & 67 & 2.52 & 0.25 & $\mathrm{~b}$ & 0.67 & 0.05 & $\mathrm{a}$ & 76.0 & 3.9 & $a, d$ \\
\hline
\end{tabular}

\section{Figures}




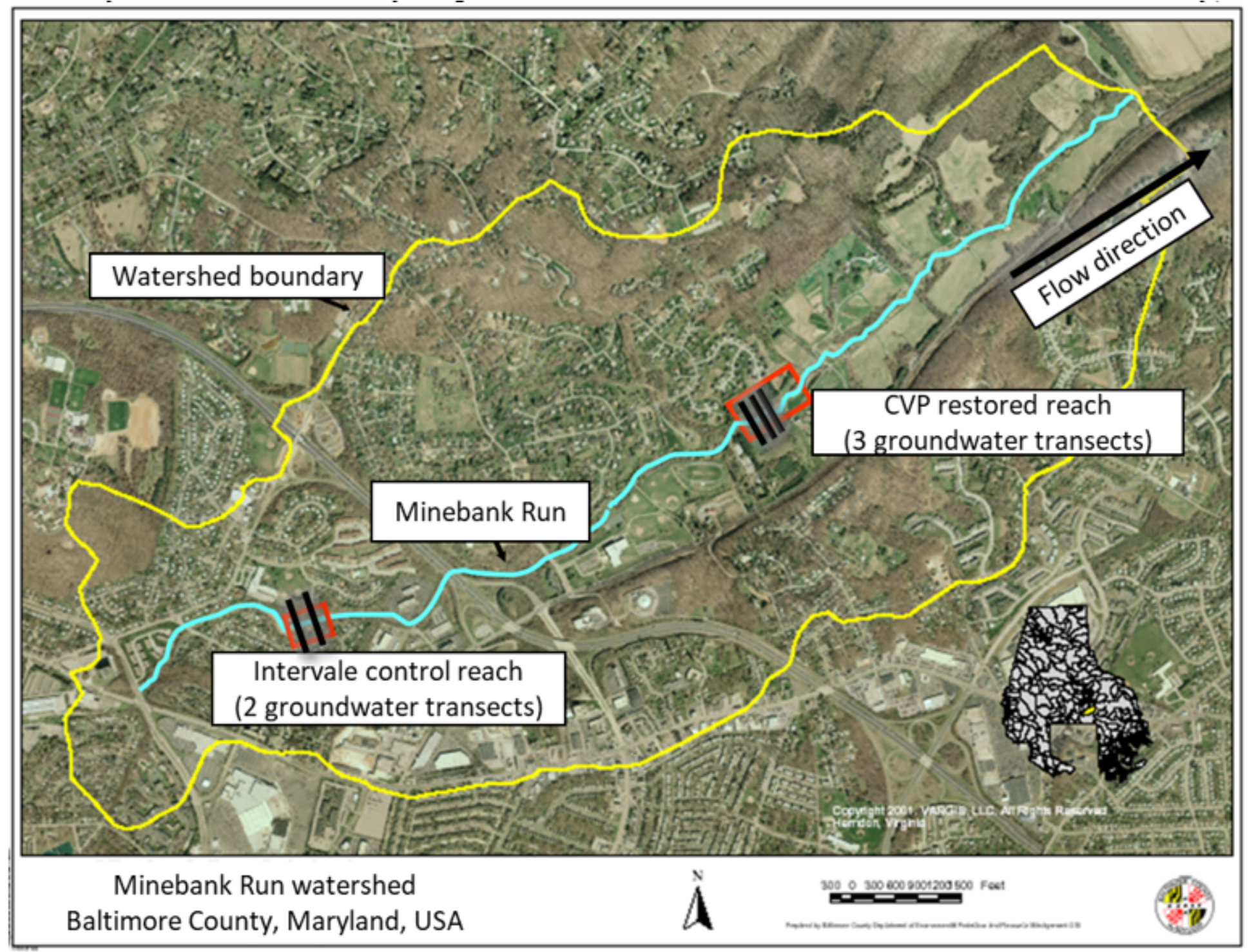

\section{Figure 1}

Aerial view of Minebank Run watershed and stream showing locations (red boxes) of study sites. Yellow line delineates the watershed. Blue line represents the stream. Stream flow is to the northwest where Minebank Run confluences with Gunpowder Falls. (Aerial photo courtesy of Baltimore County Department of Environmental Protection and Sustainability). Note: The designations employed and the presentation of the material on this map do not imply the expression of any opinion whatsoever on the part of Research Square concerning the legal status of any country, territory, city or area or of its authorities, or concerning the delimitation of its frontiers or boundaries. This map has been provided by the authors. 


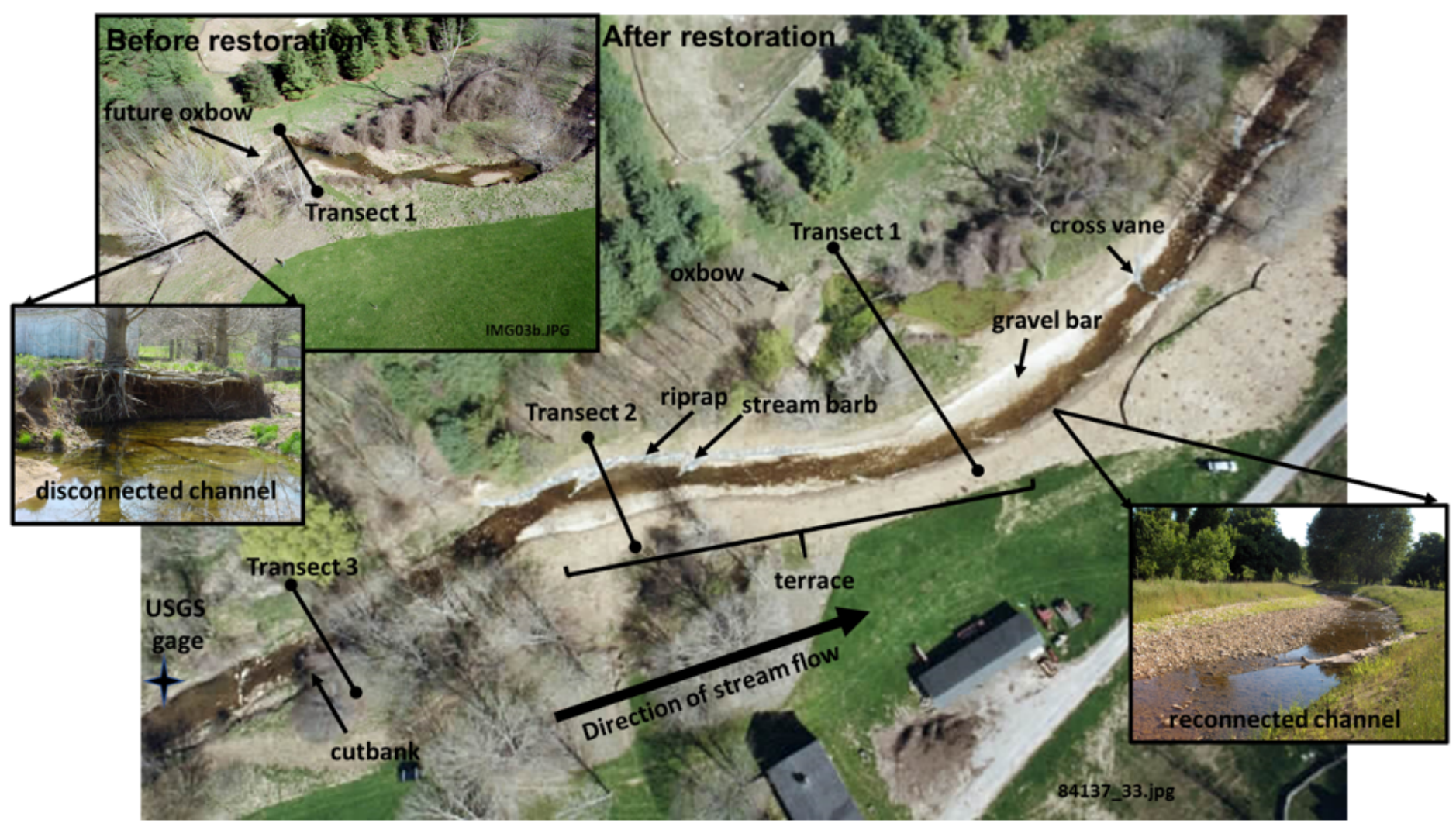

Figure 2

Aerial photos of a portion of the downstream study reach of Minebank Run showing the reconstructed stream before and after the restoration (aerial photos by K. Jewell). Note the bend in the stream channel (future oxbow) that became the oxbow after the restoration. 


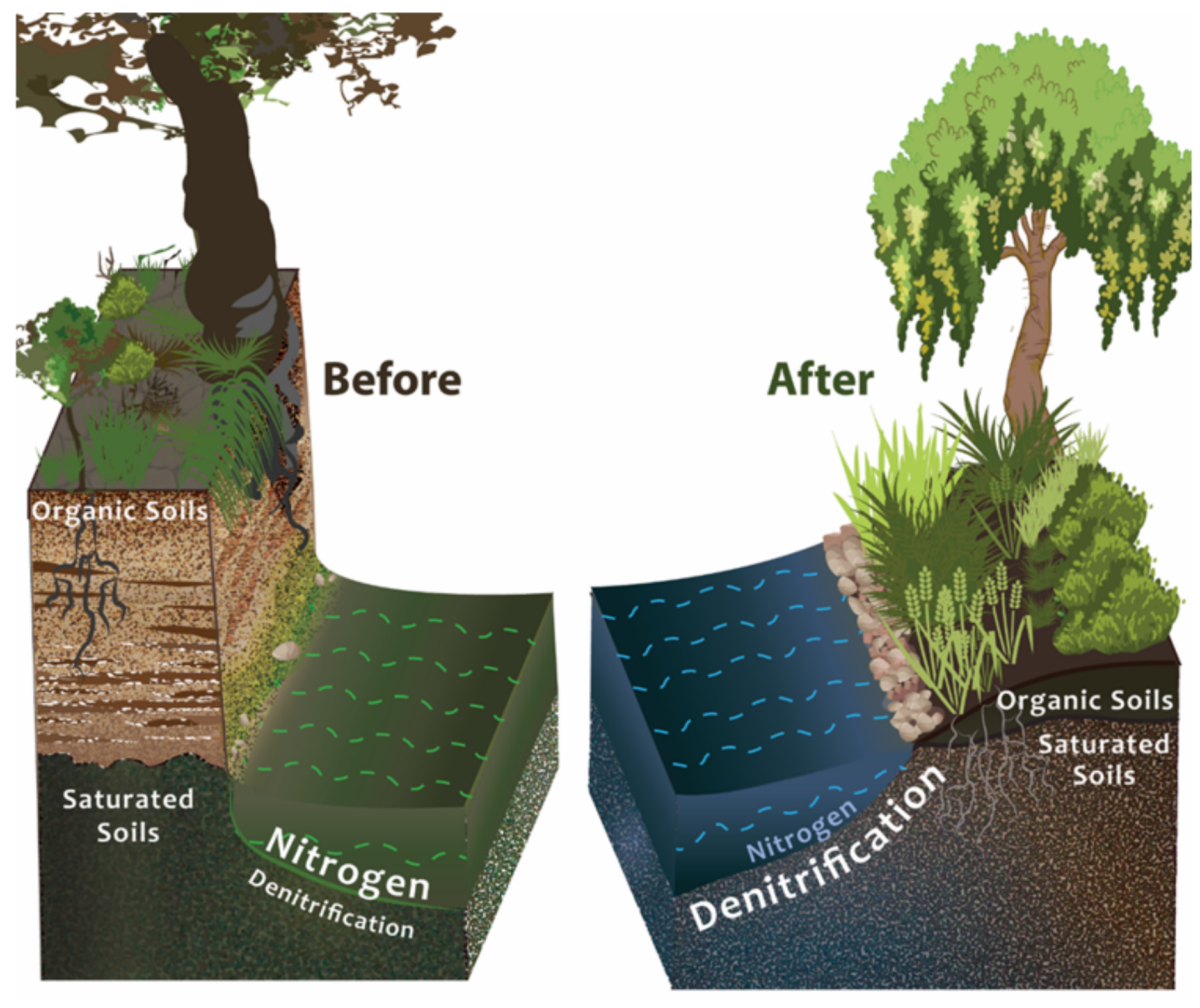

Figure 3

Conceptual figure of stream restoration to improve floodplain reconnection. Eliminating incision and reconnecting the floodplain unites saturated soils with organic matter from plants and roots and allows greater stream channel and groundwater interaction leading to more denitrification and subsequent reductions in stream nitrogen. 


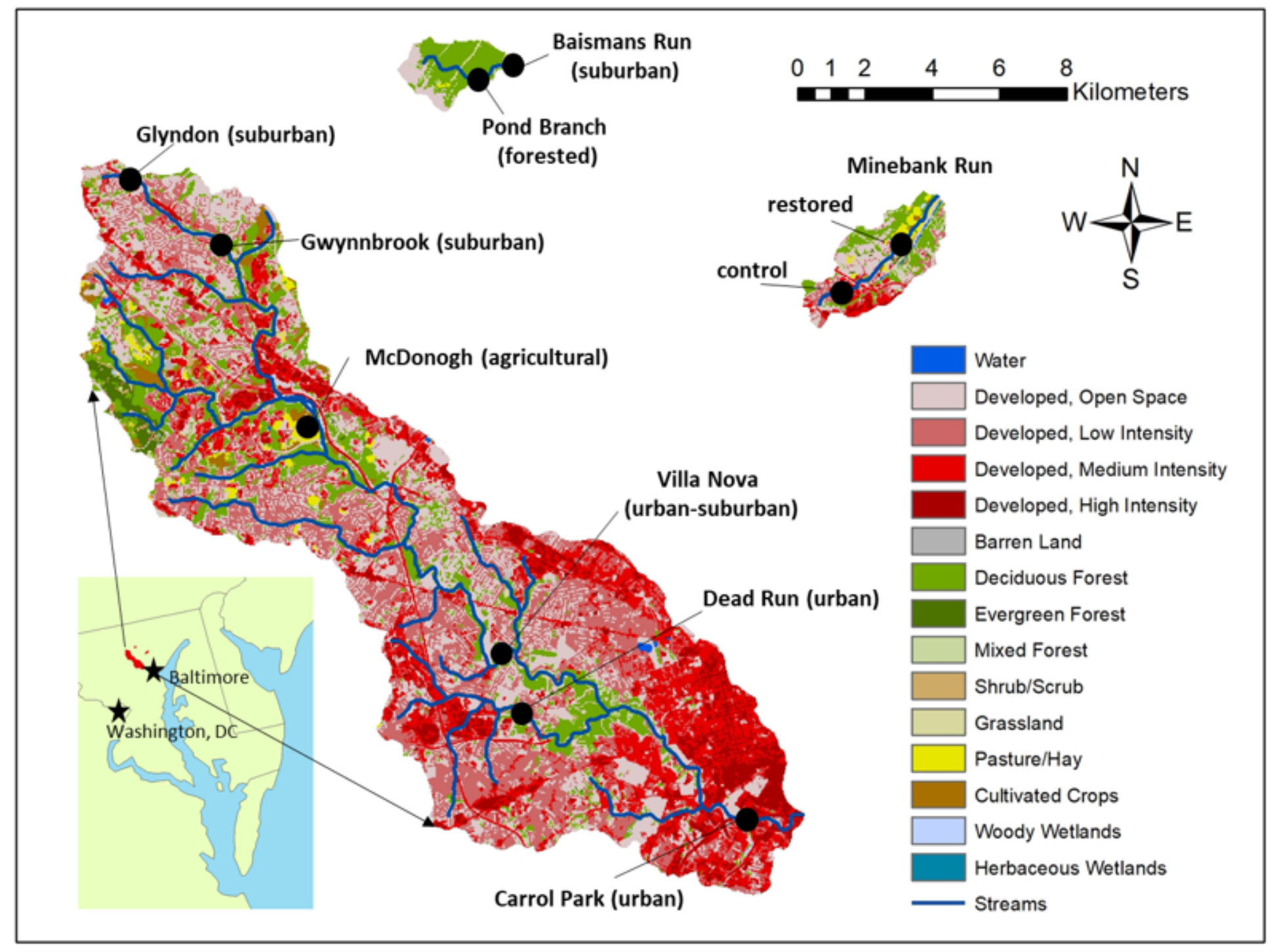

Figure 4

Study sites - Minebank Run restored and control reaches and Baltimore Ecosystem Study (BES) Long Term Ecological Research Site (LTER) stream reaches: Baisman Run, Pond Branch, Glyndon, Gwynnbrook, McDonogh, Villa Nova, Dead Run, Carroll Park Note: The designations employed and the presentation of the material on this map do not imply the expression of any opinion whatsoever on the part of Research Square concerning the legal status of any country, territory, city or area or of its authorities, or concerning the delimitation of its frontiers or boundaries. This map has been provided by the authors. 

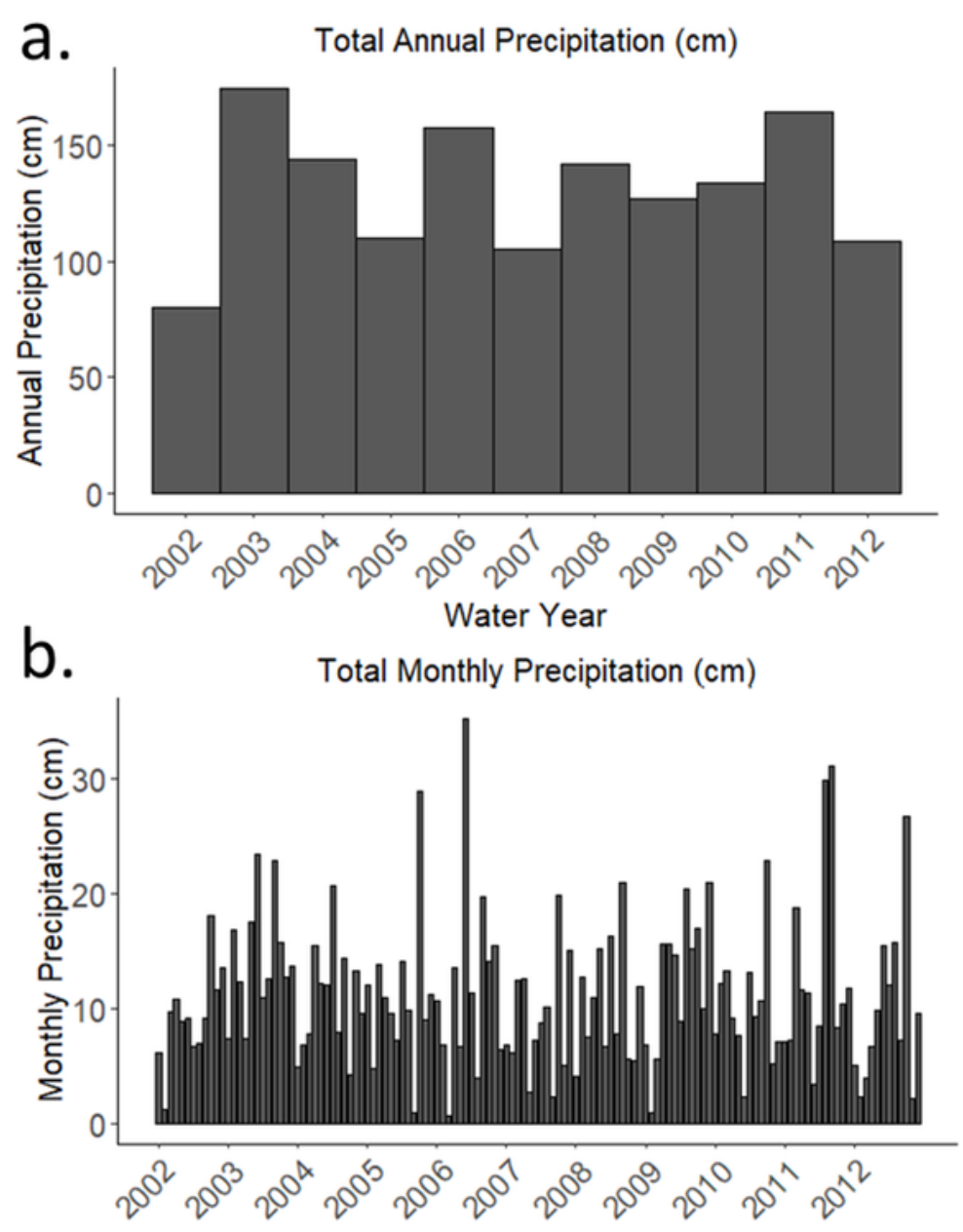

C. Total Daily Precipitation (cm)

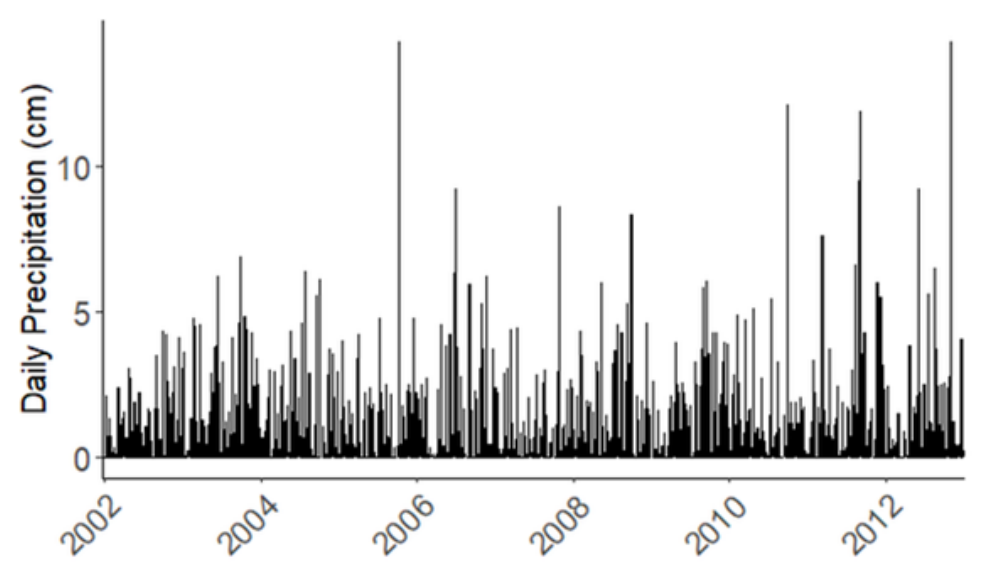

Figure 5

Change in annual, monthly, and daily precipitation, downloaded from the PRISM Climate Group (https://prism.oregonstate.edu/explorer/; latitude: 39.4200/-76.5788). 

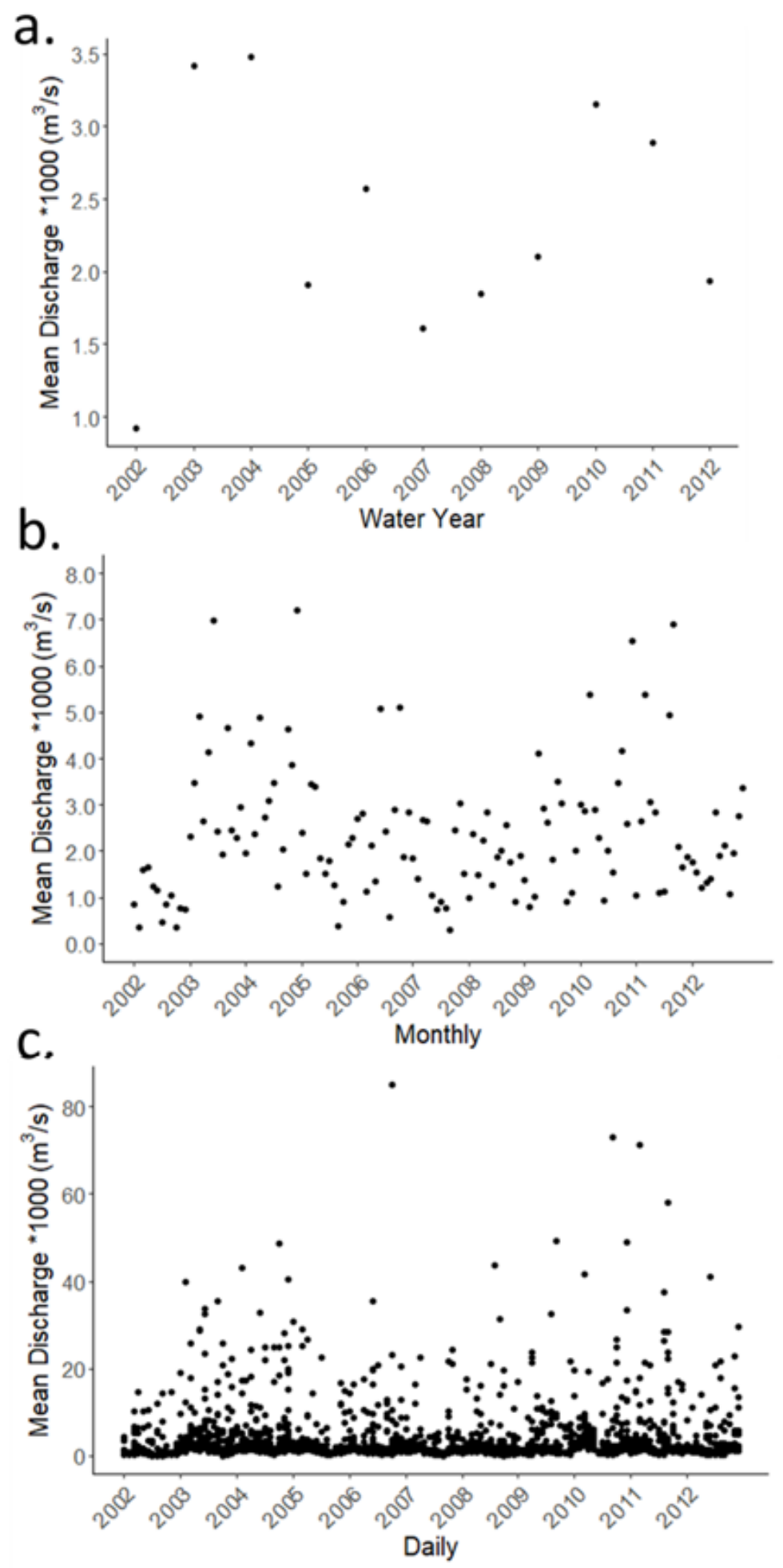

Figure 6

Mean annual, monthly, and daily discharge at Minebank Run restored CVP reach (USGS gage 0158397967). 

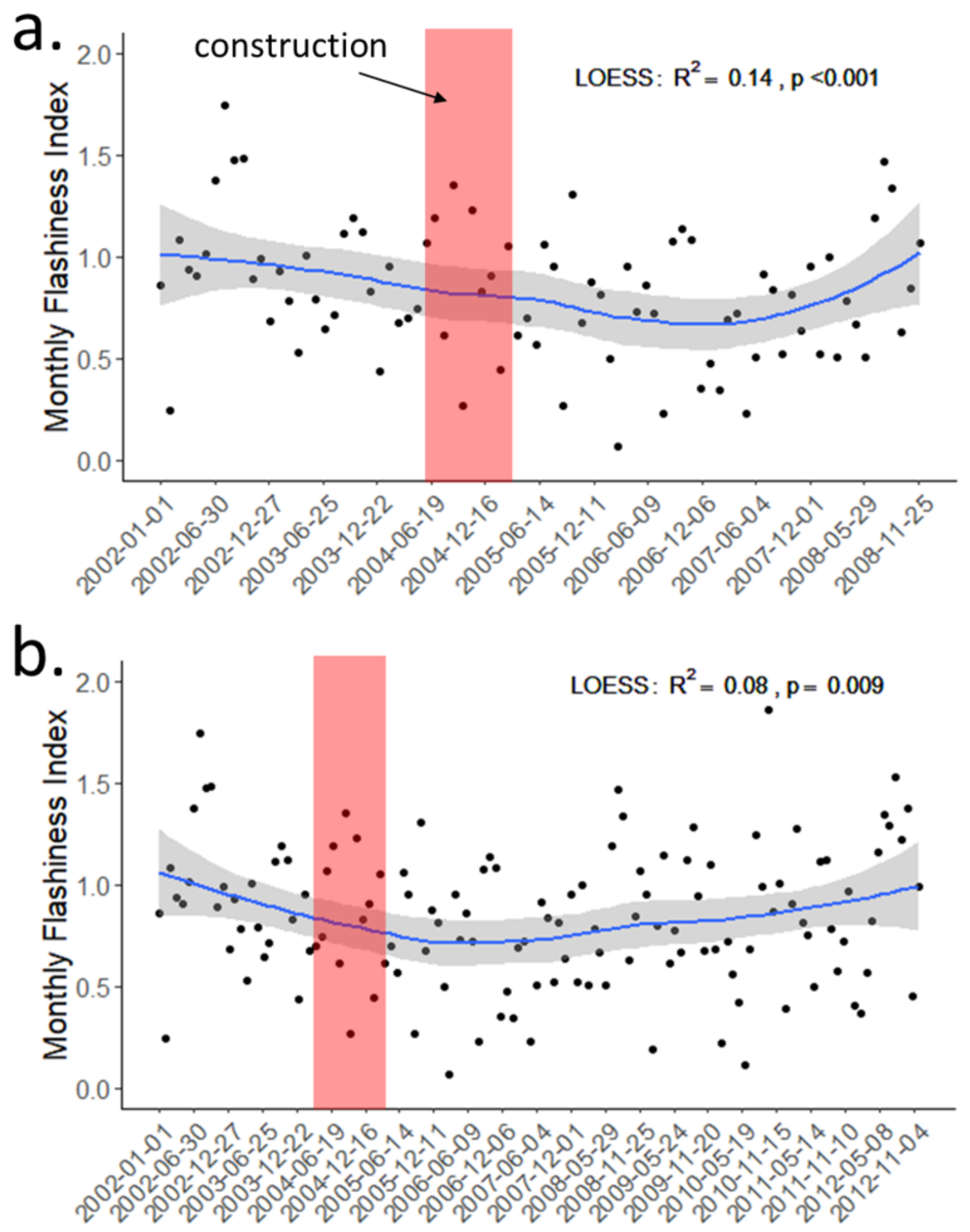

Figure 7

The average monthly Hydrologic Flashiness Index: a) from 2002-2008 and b) from 2002-2012. 

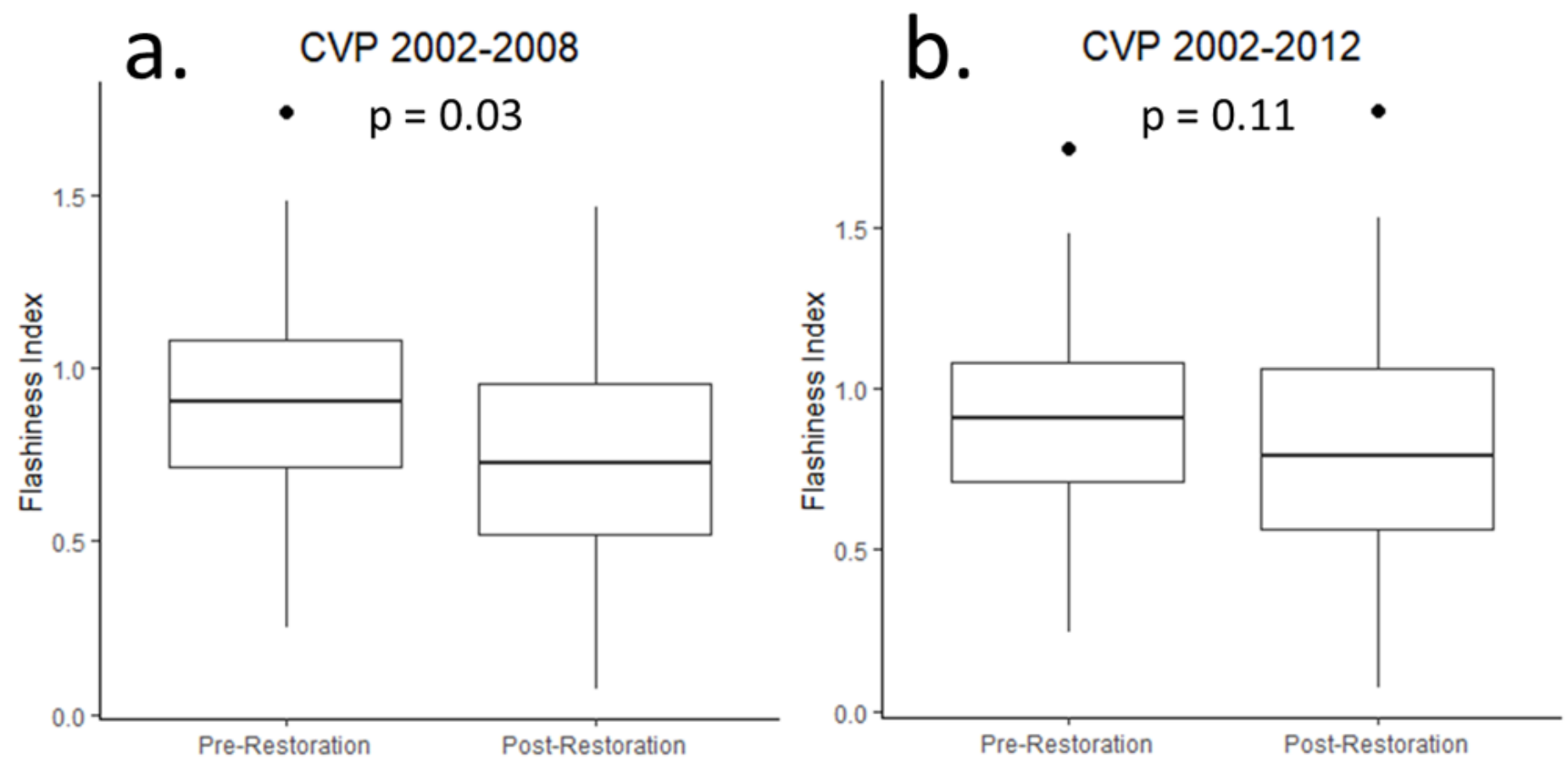

Figure 8

Hydrologic flashiness compared during pre- and post-restoration periods for (a) 2002-2008 and (b) 20022012. 

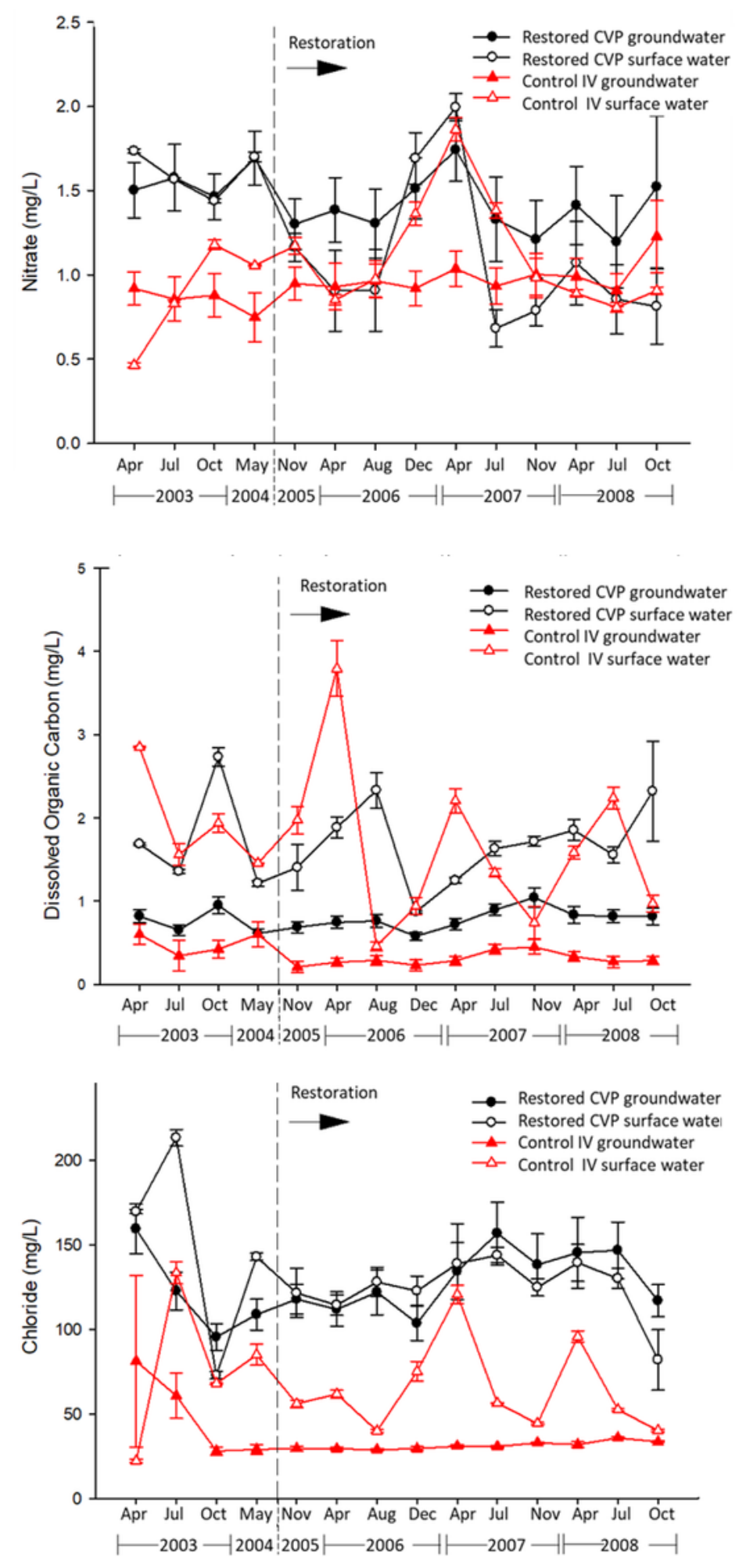

\section{Figure 9}

Minebank Run restored CVP and control IV reaches, NO3-, DOC, and Cl- concentrations (mg/L) in groundwater and surface water. Time is not to scale. 


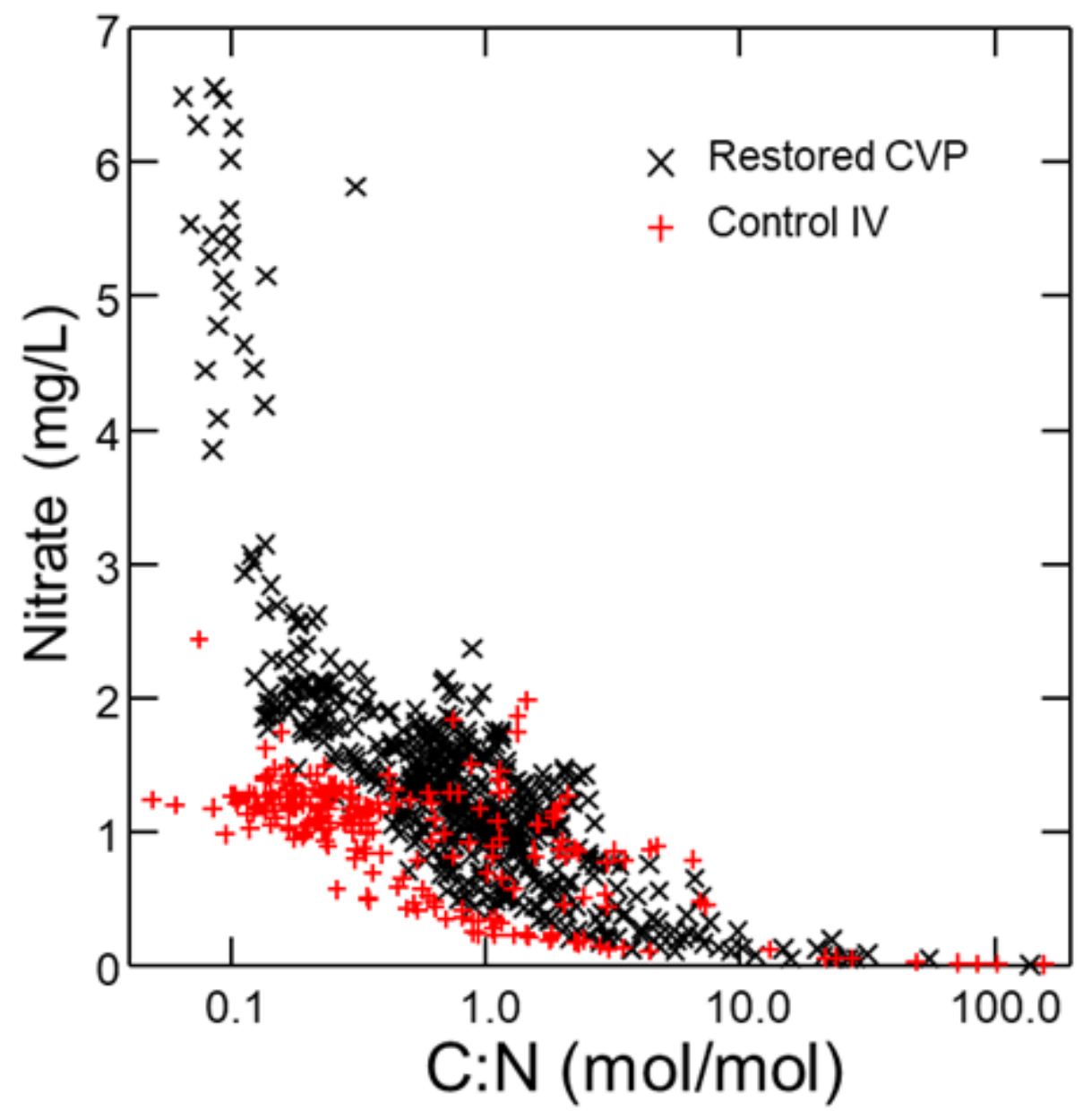

Figure 10

At Minebank Run, at both restored CVP reach and the control IV reach, groundwater NO3- versus molar ratios of C:N exhibit a similar negative curvilinear relationship. 

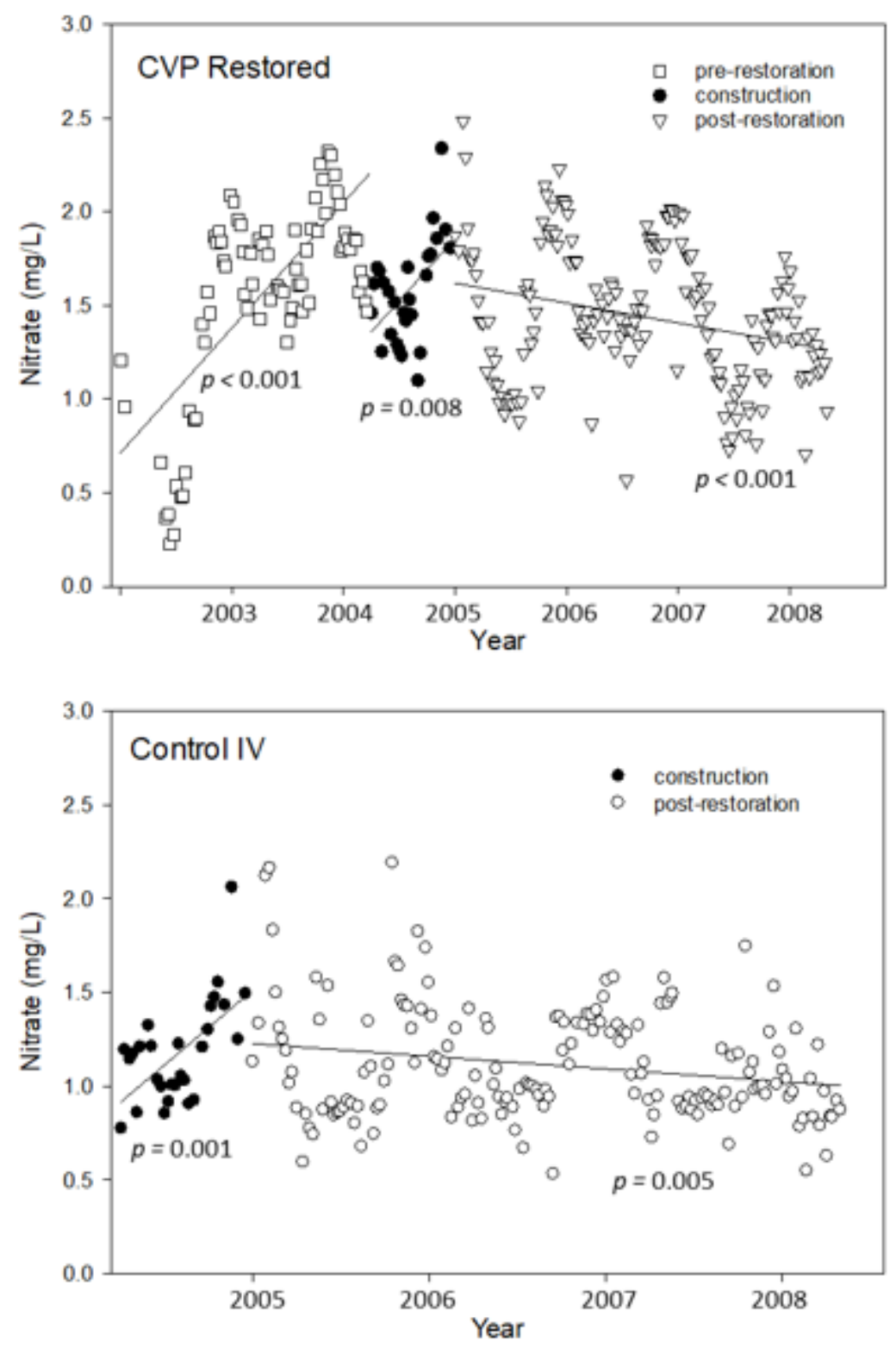

Figure 11

USGS bi-weekly Minebank Run surface water NO3- concentrations (mg/L) at restored CVP and control Intervale. NO3- shows increasing trends prior to the restoration and during construction at the restored, downstream CVP reach. NO3- trends decline steadily after the restoration. Seasonal cycles are evident and NO3- was especially low during a severe drought in 2002 and then rose concurrently with a rapid shift to a wet season in 2003. 

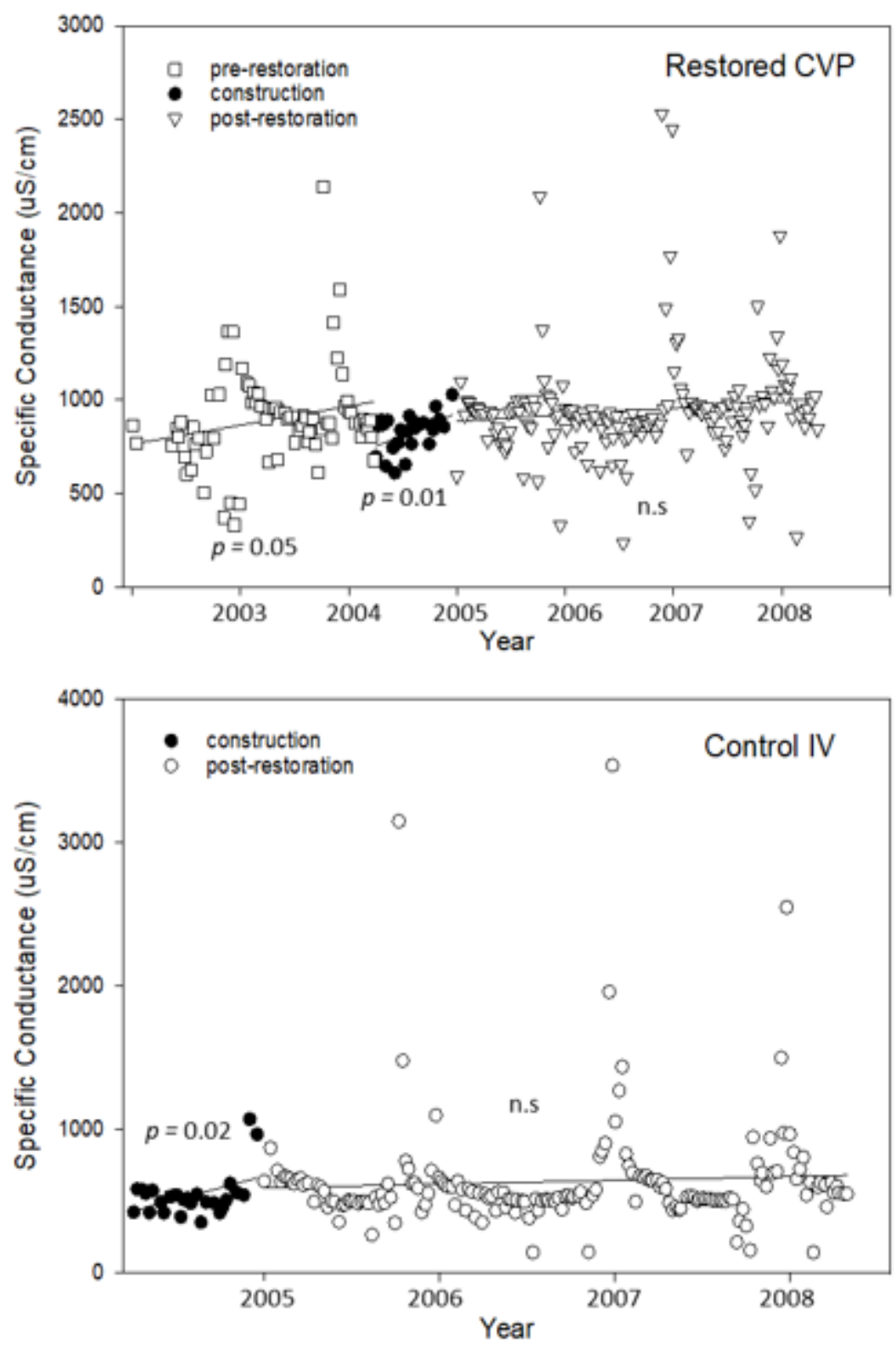

Figure 12

USGS bi-weekly Minebank Run surface water specific conductance $(\mu \mathrm{S} / \mathrm{cm})$ at restored CVP and control Intervale. Surface water in samples collected bi-weekly at restored CVP reach. Specific conductance is generally higher at restored CVP than at the upstream control Intervale because of the influence of the I695 beltway and associated inputs of road salts. Trends overall appear to be increasing with occasional extreme peaks from storm runoff suggesting that road salts and/or other ions are influencing water chemistry at Minebank Run. 

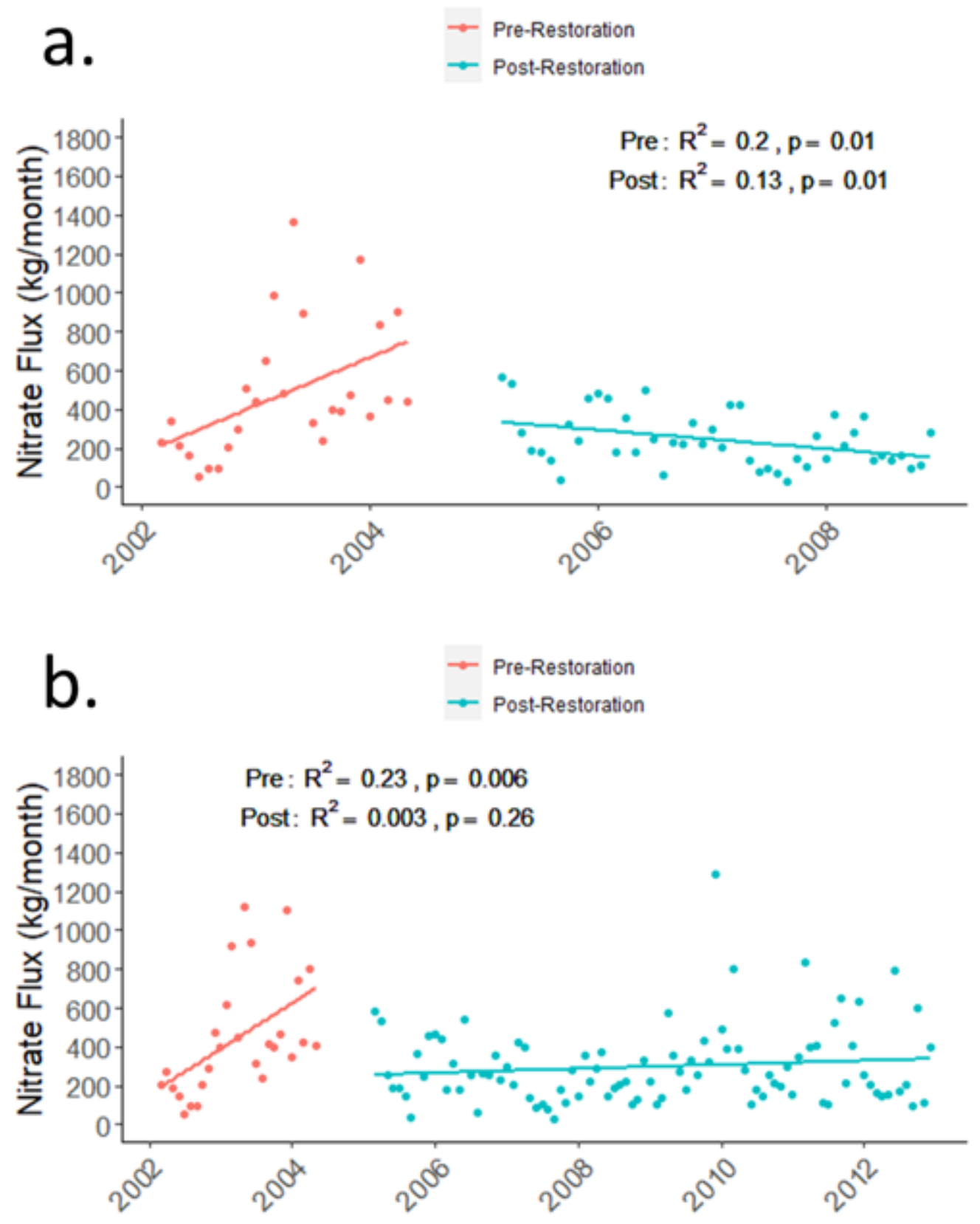

Figure 13

Trends in NO3- flux (kg/month) compared during pre- and post-restoration periods for (a) 2002-2008 and (b) 2002-2012. 

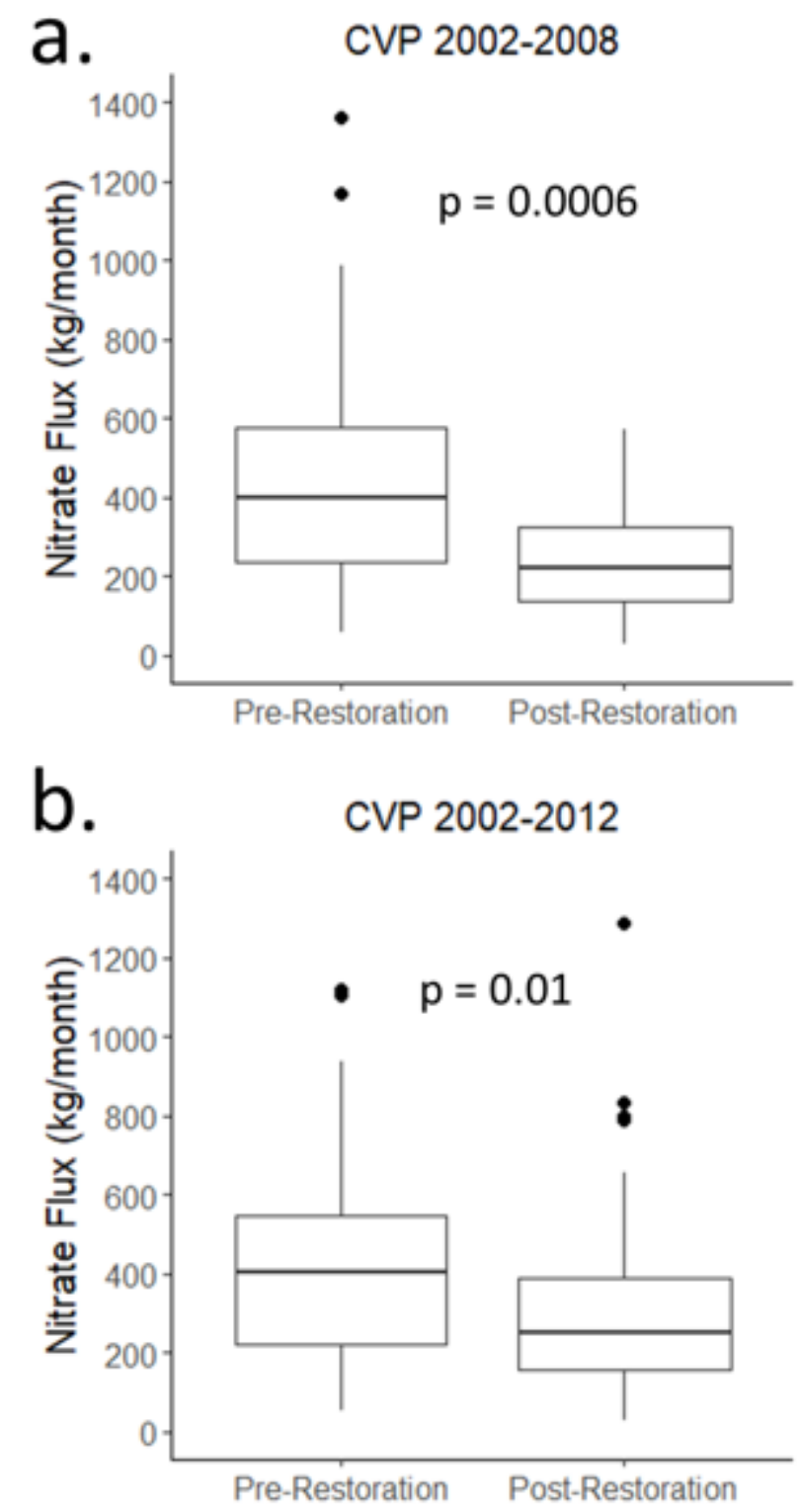

Figure 14

Pre- and post-restoration box plots of monthly NO3- flux (kg/month) at Minebank Run for (a) 2002-2008 and (b) 2002-2012. 


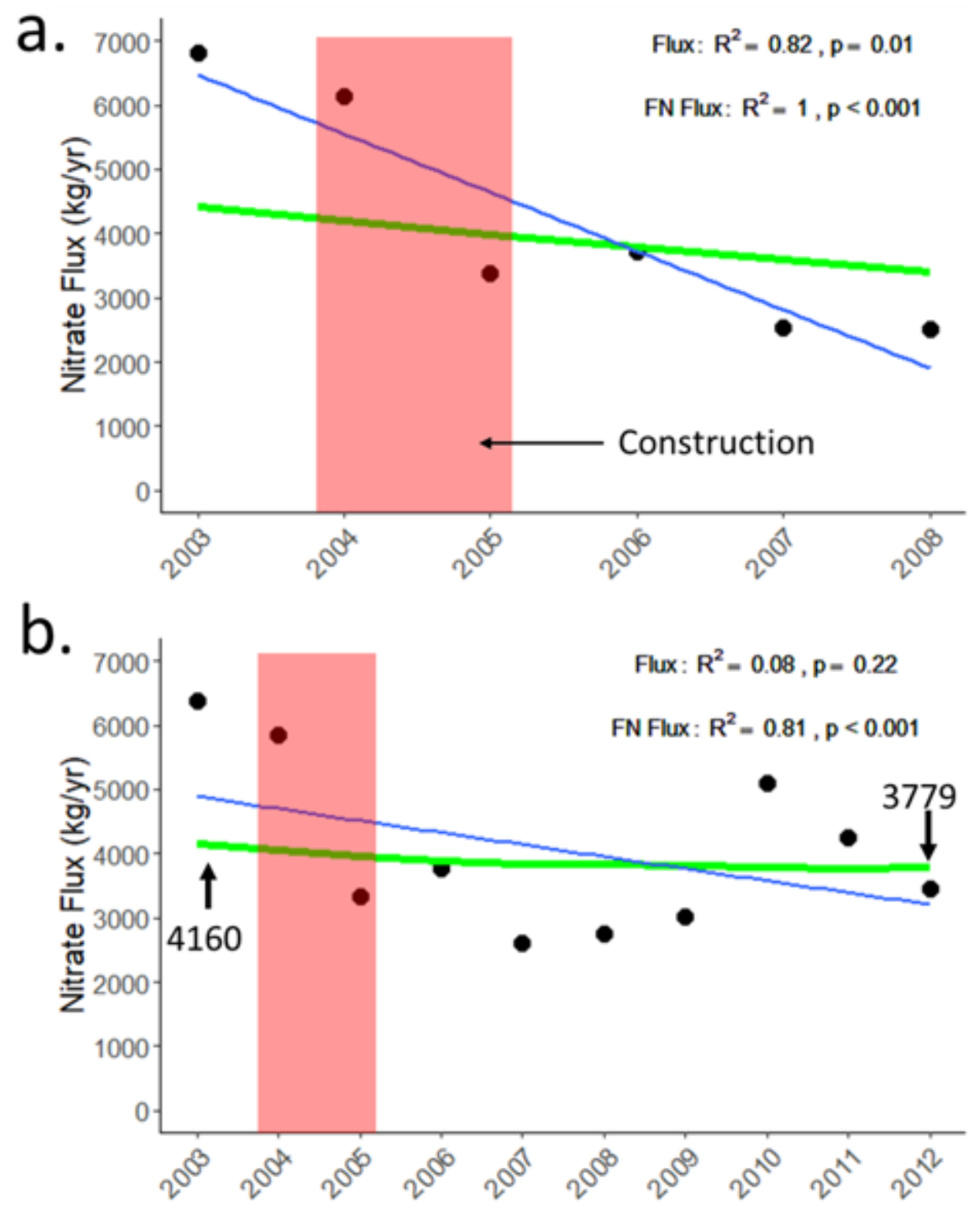

Figure 15

Annual average NO3- flux (black dots and blue trendline) and flow normalized (FN; green) flux at Minebank Run for the (a) 2002-2008 and (b) 2002-2012. 

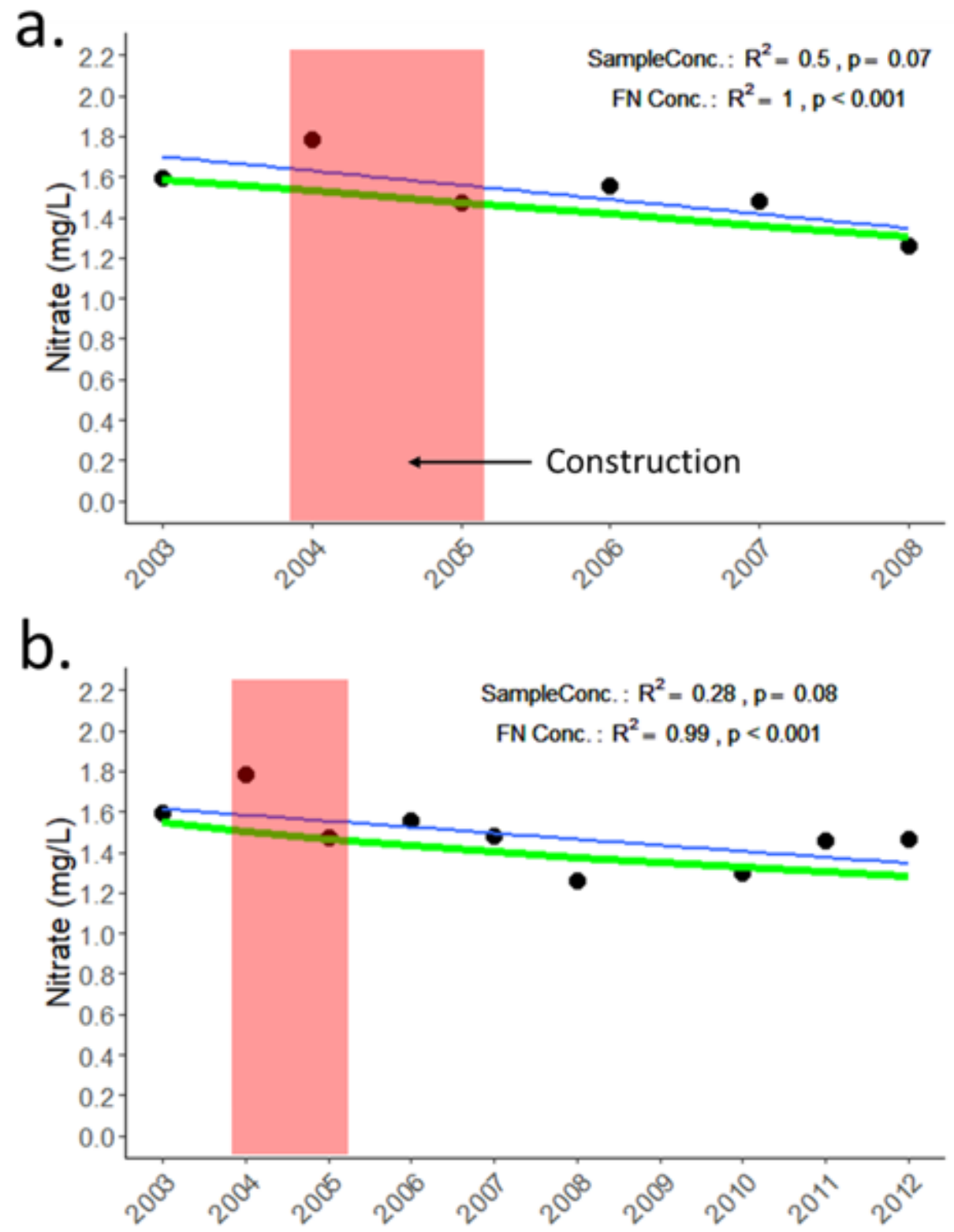

Figure 16

Annual mean NO3- concentration (black dots and blue trendline) and flow normalized concentration trends (green) for the (a) 2002-2008 and (b) 2002-2012. 
a.

\section{CVP 2002-2008}

\section{Pre-Restoration}

$\rightarrow$ Post-Restoration

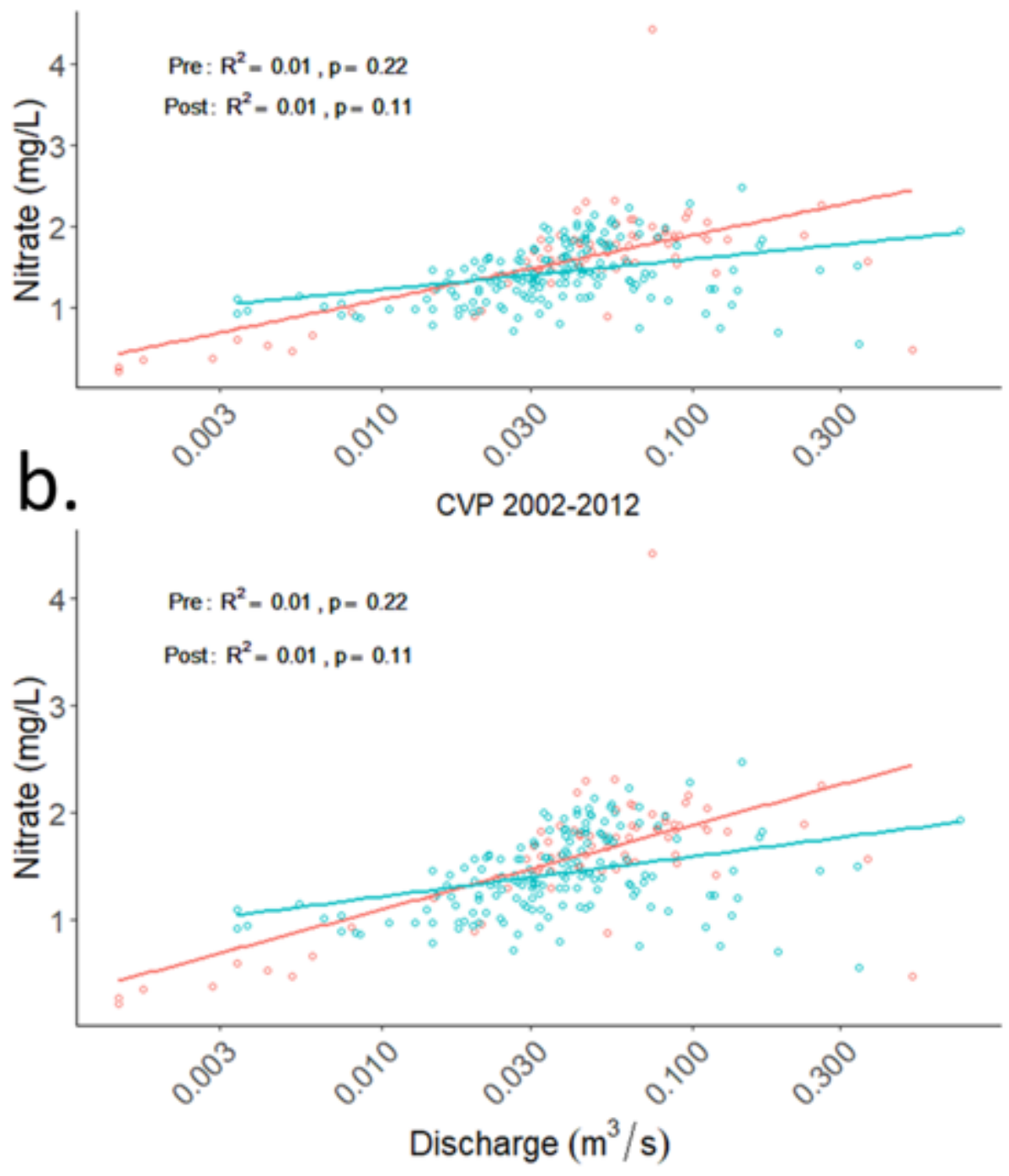

Figure 17

Concentration vs. discharge relationship compared during pre- and post-restoration periods for (a) 20022008 and (b) 2002-2012. 

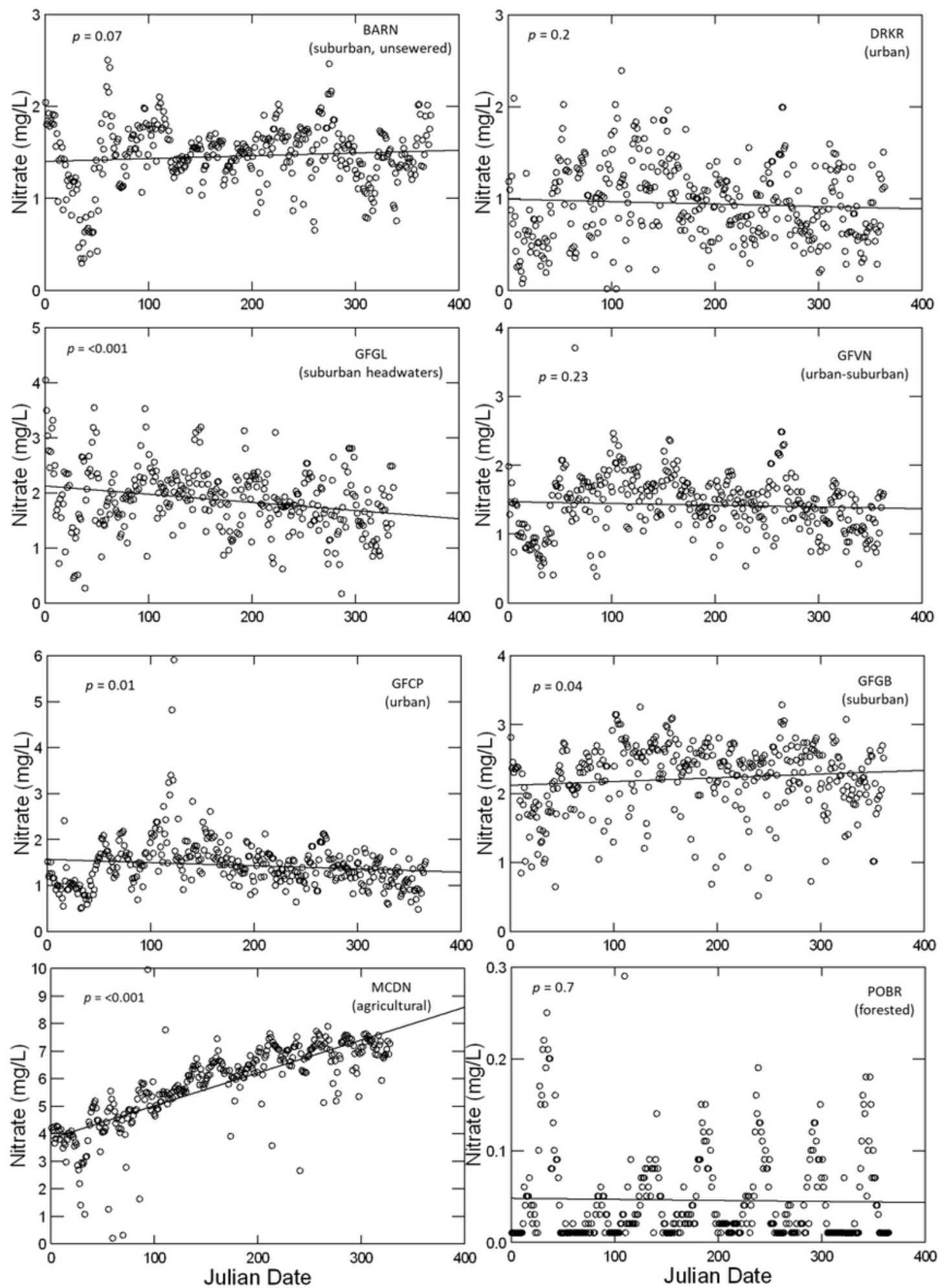

\section{Figure 18}

Linear regression trends of nitrate (NO3-) concentrations (mg/L) in surface water over time (2002-2008) among BES LTER streams; Baisman Run (BARN), Dead Run (DRKR), Gwynns Falls at Carroll Park (GFCP), Gwynns Falls at Gwynbrook Ave (GFGB), Gwynns Falls at Glyndon (GFGL), Gwynns Falls at Villa Nova (GFVN), McDonogh (MCDN), Pond Branch (POBR). Julian dates begin 3 Jan 2002 and samples were collected approximately weekly at sites through 30 Dec 2008. Data source: 
https://portal.edirepository.org/nis/metadataviewer?packageid=knb-lter-bes.700.600; file: BES-streamchemistry-data-for-WWW-feb-2018--core-sites-only.cvs
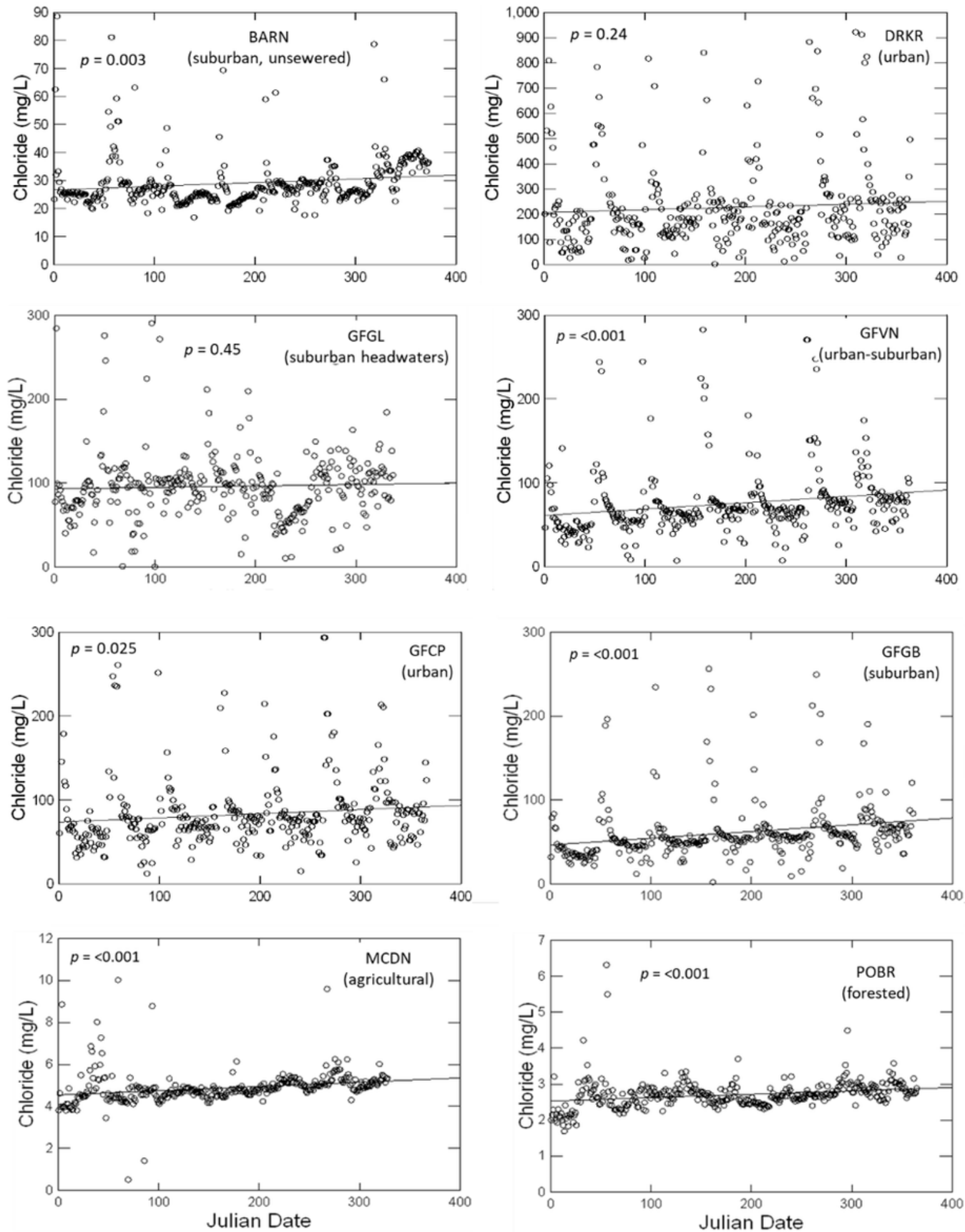

\section{Figure 19}

Linear regression trends of chloride $(\mathrm{Cl})$ concentrations $(\mathrm{mg} / \mathrm{L})$ in surface water over time (2002-2008) among BES LTER streams; Baisman Run (BARN), Dead Run (DRKR), Gwynns Falls at Carroll Park (GFCP), Gwynns Falls at Gwynbrook Ave (GFGB), Gwynns Falls at Glyndon (GFGL), Gwynns Falls at Villa Nova 
(GFVN), McDonogh (MCDN), Pond Branch (POBR). Julian dates begin 3 Jan 2002 and samples were collected approximately weekly at sites through 30 Dec 2008. Data source:

https://portal.edirepository.org/nis/metadataviewer?packageid=knb-Iter-bes.700.600; file: BES-streamchemistry-data-for-WWW-feb-2018--core-sites-only.cvs

\section{Supplementary Files}

This is a list of supplementary files associated with this preprint. Click to download.

- Supplementallnformation.docx 